\title{
Chemical and mineral composition of ashes from wood biomass combustion in domestic wood-fired furnaces
}

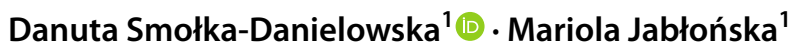

Received: 12 January 2021 / Revised: 6 June 2021 / Accepted: 23 June 2021 / Published online: 4 July 2021

(c) The Author(s) 2021

\begin{abstract}
The paper presents the results of studies on ashes produced from burning wood biomass in closed wood-fired furnaces, in individual household furnaces (Silesian Province, Poland). Dry sieve analysis and detailed granulometric analysis were performed with the Analysette 22 Micro Tec plus analyser. Content of the basic elements (Al, Si, P, Na, K, Mg, Ca, Fe) and potentially toxic elements ( $\mathrm{As}, \mathrm{Pb}, \mathrm{Cd}, \mathrm{Zn}, \mathrm{Cu}, \mathrm{Ni}, \mathrm{Cr}, \mathrm{Hg}$ ) was determined by atomic absorption spectrometry (AAS) and inductively coupled plasma mass spectrometry (ICP-MS). Relative enrichment factors $\left(\mathrm{REF}_{\mathrm{S}}\right)$ were calculated for the elements ( $\mathrm{Pb}, \mathrm{Cd}, \mathrm{Zn}, \mathrm{Cu}, \mathrm{Ni}, \mathrm{As}, \mathrm{Hg}$, and $\mathrm{Cr}$ ), and the emissions (E) of $\mathrm{Pb}, \mathrm{Cd}, \mathrm{Hg}$, and As to the environment were estimated. The carbon content (40.2\%-45.8\%), H (3.7\%-6.1\%), O (46.2\%-50.2\%), N (0.12\%-0.32\%), and S (0.11\%-0.96\%) in wood biomass varies and depends on the wood species and drying period. The content of volatile parts in wood biomass ranges between 69.3 and $81 \%$. Ash content varies between 2.6 and $18.3 \%$. The wood calorific value ranges from $13.6 \mathrm{MJ} / \mathrm{kg}$ to $17.4 \mathrm{MJ} / \mathrm{kg}$. Moisture content in the wood biomass ranges from $13.7 \%$ (briquette) to $46.7 \%$ (fresh birch). Identification of mineral composition and phases yields a high share of calcite, monetite, fairchildite, and quartz in the examined ashes. The combustion of wood biomass in fireplaces results in increased emissions of $\mathrm{Pb}$ and $\mathrm{Cd}$ to the atmosphere and may be the cause of introducing pollutants to waters and soils during ash storage.
\end{abstract}

Keywords Chemical composition $\cdot$ Emission factor $\cdot$ Fireplace $\cdot$ Wood ash

\section{Introduction}

Wood is used for heating homes in many countries. The highest per capita consumption of firewood was recorded in Scandinavian and Baltic countries (5-15 GJ/person) and in Europe (2-10 GJ/person) (Deniver et al. 2015).

Individual domestic furnaces in open and closed fireplaces mainly generate ash from burning wood and briquettes produced based on hardwood and coniferous wood. Ash from burning wood biomass is widely recognised as potentially harmless to the environment. In Poland, in 2018, the consumption of biomass from wood in individual fireplaces reached 13.2\% (GUS 2019), while in other EU countries it was about $16 \%$ (Faraca et al. 2019). It is estimated

Editorial responsibility: Nour Sh. El-Gendy.

Danuta Smołka-Danielowska

danuta.smolka-danielowska@us.edu.pl

1 Faculty of Natural Sciences, University of Silesia, Będzińska Str. 60, 41-200, Sosnowiec, Poland that pollution emissions from wood combustion in residential buildings account for approximately $45 \%$ of PM2.5 dust and may have a significant impact on the air quality in a given region (Martin et al. 2013; Daellenbach et al. 2016; Maasikmets et al. 2016; Corsini et al. 2017; Czech et al., 2018b, a; Trojanowski and Fthenakis 2019).

The World Health Organisation (WHO) believes that such emissions are one of the major global environmental risk factors (Carvalho et al. 2016; Tao et al. 2016; Vincente and Alves, 2018; Padilla-Barrera et al. 2019). In the process of wood biomass combustion, inorganic components can be distributed between the gaseous product and the solid ash fraction (Thy et al. 2017). It is estimated that almost $70 \%$ of PM2.5 comes from wood burning in fireplaces and 30\% from wood boilers (WHO 2015). The contribution of wood burning to air pollution varies and according to WHO (2015) during the heating season, PM2.5 emissions range from 30 to $90 \%$ and PM10 emissions range from 10 to $81 \%$. In Denmark, PM2.5 emissions from wood combustion are around $67 \%$. The highest share of PM2.5 from wood combustion was found in the winter 
season in Australia (Launceston) with 95\%, followed by the USA (Fairbanks) with values ranging between 60 and $80 \%$. In the southern part of Germany, PM2.5 emissions from wood combustion account for around 59\%. In Italy, wood burning in urban households causes an increase in particulate matter from 18 to $76 \%$, and in rural areas from 40 to $85 \%$ (Siergiej and Jędrak 2019). A typical fireplace for seasoned wood emits up to $1350 \mathrm{mg}$ of particulate matter $/ \mathrm{m}^{3}$ and up to $2180 \mathrm{mg}$ of particulate matter $/ \mathrm{m}^{3}$ when burning damp wood, while a fireplace complying with emission standards only emits about $40 \mathrm{mg}$ of particulate matter $/ \mathrm{m}^{3}$ (Kubica and Kubica 2016).

According to Alves et al. (2011), the emission factor for biomass combustion in residential buildings is $17.3 \mathrm{~g} /$ kg PM2.5 (Maenhaut et al. 2012; Martin et al. 2013; Cincinelli et al. 2019). Considering the chemical composition of ash and its potential applications, attention should be paid to the content of alkaline and potentially toxic elements (Czop and Kajda-Szcześniak 2010, 2013; Kajda-Szcześniak 2014). According to Vassilev et al. (2012), dried wood contains: $49.5 \% \mathrm{C}, 6.3 \% \mathrm{H}, 44.2 \% \mathrm{O}$, $0.04-0.26 \% \mathrm{~N}$ and $0.2-2.3 \%$ mineral compounds. Natural biomass is enriched with such elements as: $\mathrm{Ca}, \mathrm{Cl}, \mathrm{H}, \mathrm{K}$, $\mathrm{Mg}, \mathrm{Mn}, \mathrm{O}$, and P (Vassilev et al. 2010; Michalik and Wilczyńska-Michalik 2012; Mirowski 2016). $\mathrm{CaO}, \mathrm{SiO}_{2}$, $\mathrm{K}_{2} \mathrm{O}$ provide for the largest share in wood biomass (Vassilev et al. 2010; Ban and Ramli 2011; Garcia et al. 2015). Ashes from wood combustion also contain potentially toxic elements, such as $\mathrm{As}, \mathrm{Cd}, \mathrm{Ba}, \mathrm{Cr}, \mathrm{Cu}, \mathrm{Ni}, \mathrm{Pb}$, and Zn (Cuenca et al. 2013; Vassilev et al. 2014; Berra et al. 2015; Uliasz-Bocheńczyk and Mokrzycki 2018). According to Jukić et al. (2017) ash from wood burning is characterised by high $\mathrm{Zn}$ and $\mathrm{Cu}$ content and low $\mathrm{Cd}$ and $\mathrm{Hg}$ content. The phase composition of ashes from biomass mainly includes of calcite, sylvite, arcanite, apatite, anhydrite, periclase, hematite, and unburned carbon (Vassilev et al. 2013; Magdziarz et al. 2018).

The extreme variety of wood biomass burned in households requires a thorough analysis of its physicochemical properties.

This study aimed to identify the potential hazard related to burning wood in fireplace-type furnaces in households. It is important to determine the concentrations of major, potentially toxic elements and phase composition of ashes as this waste is managed by stored and used in agriculture. Most fireplaces in Poland do not meet emission standards and thus contribute to an increase in air pollution with particulate matter. The number of pollutants emitted depends also on the type and quality of wood (e.g. its humidity). We estimated emission to the atmosphere of the most toxic elements $(\mathrm{Pb}, \mathrm{Cd}, \mathrm{Hg}$, and $\mathrm{As})$, for which data on emission factors can be obtained.

\section{Materials and methods}

\section{Material for analysis}

The type of biomass and its physical and chemical parameters are part of the framework quality requirements of a given energy group. There is a common reference source for quality requirements for solid biomass, which is most often the PN-EN ISO 17,225-1:2014-07 standard. It contains specifications for individual fuels and classes (PNEN ISO 17,225-5:2014-07-Part 5: Firewood; PN-EN ISO 17,225-3:2014-07-Part 3: Wood briquettes).

Ash is produced after burning fresh (birch and alder) and seasoned wood (birch, beech, oak, spruce) as well as briquettes made of sawdust from deciduous and coniferous wood (beech and oak-85\%, pine chips-15\%). Sawdust for the production of briquettes are leftovers from the production of wood accessories. The test samples included ashes from two wood-fired furnaces of the "closed fireplace" type, each with thermal power of $18 \mathrm{~kW}$ and thermal efficiency of approximately $70-72 \%$. The combustion temperature did not exceed $500{ }^{\circ} \mathrm{C}$. Deciduous wood (birch and alder) came from the Andrychów Forest District (Małopolskie Voivodeship), beech and oak from the Silesian Voivodeship, and the briquettes were produced in Poland. In each furnace from which the ashes were taken for analysis approximately $4 \mathrm{~m}^{3}$ of wood were burnt during the heating season. We analysed ash from fresh wood (seasoned for about 3 months) and seasoned wood (dried for about 2-3 years). Samples were taken and prepared for analysis in accordance with PN-EN ISO 18,135:2017-06 and PN-EN ISO 14,780:2017-07 standards.

In total, 14 samples were analysed, 2 samples for each ash type. All the samples of ash from wood combustion with a mass of approximately $1 \mathrm{~kg}$ were reduced using the quartering technique (leading to a halving of the sample mass). On completion of this process, we obtained two parts from each ash sample, which were combined and subjected to sieve analysis. For each ash sample, we separated two fractions with grain sizes $<100 \mu \mathrm{m}$ and $>100 \mu \mathrm{m}$. For each of the seven ash fractions (except for biomass analyses for $\mathrm{C}, \mathrm{O}, \mathrm{H}, \mathrm{N}, \mathrm{S}, \mathrm{Cl}$ ), we prepared five analytical samples. Table 1 contains the codes for samples of ash from the combustion of wood biomass.

The working methods are presented in the block diagram (Supplementary Information).

\section{Test method}

Control of biomass quality parameters includes analysis of ash content, moisture content, volatile parts, and calorific 
Table 1 Sample codes for analytical tests

\begin{tabular}{lllll}
\hline \multicolumn{2}{l}{ Sample code } & $\begin{array}{l}\text { Type of ash } \\
\text { Ash fraction }<100 \mu \mathrm{m}\end{array}$ & $\begin{array}{l}\text { Sample code } \\
\text { Ash fraction }>100 \mu \mathrm{m}\end{array}$ & Type of ash \\
\hline 1 & $1 \mathrm{~A}$ & Seasoned alder & $1 \mathrm{~B}$ & Seasoned alder \\
2 & $2 \mathrm{~A}$ & Seasoned birch & $2 \mathrm{~B}$ & Seasoned birch \\
3 & $3 \mathrm{~A}$ & Fresh birch & $3 \mathrm{~B}$ & Fresh birch \\
4 & $4 \mathrm{~A}$ & Seasoned alder and oak (1/2 ratio) & $4 \mathrm{~B}$ & Seasoned: alder and oak (1/2 ratio) \\
5 & $5 \mathrm{~A}$ & Seasoned: beech, alder and oak (1/3 ratio) & $5 \mathrm{~B}$ & Seasoned: beech, alder and oak (1/3 ratio) \\
6 & $6 \mathrm{~A}$ & Seasoned: beech and spruce (1/3 beech and 2/3 & $6 \mathrm{~B}$ & Seasoned beech and spruce (1/3 beech \\
& & Spruce) & & and $2 / 3$ spruce $)$ \\
7 & 7 & Wood sawdust briquette &
\end{tabular}

value. The calorific value is an important parameter in biomass analysis because it depends on the moisture and composition of the burned wood. The moisture content in wood affects its calorific value. The mineral content of wood is determined from the ash content, which depends on the type of wood. The chemical composition of biomass ash features a high content of alkaline compounds which affect its meltability. Ashes from biomass combustion exhibit large differences in concentration of potentially toxic elements (e.g. $\mathrm{Pb}, \mathrm{Cd}, \mathrm{As}$ ). The differences in the grain size of the examined ashes result from the type of the burned wood. Most often, ashes from wood combustion are characterised by very fine grain size (Mashio et al. 2011).

Dry sieve analysis was performed and two fractions of ashes were separated for further testing: fine (grain size below $100 \mu \mathrm{m}$ ) and coarse (grain size above $100 \mu \mathrm{m}$ ). Analysette 22 Micro Tec plus laser particle size meter was used for detailed granulometric analysis.

Concentrations of basic elements ( $\mathrm{Na}, \mathrm{K}, \mathrm{Ca}, \mathrm{Mg}, \mathrm{Si}$, $\mathrm{Al}, \mathrm{Fe}$ ) in ash samples for selected wood species were determined using atomic absorption spectrometry (AASThermo Scientific SOLAAR M6), and for potentially toxic elements (As, Cd, Cu, Cr, Hg, Ni, Pb, Zn, Mn, and Ba), it was determined using ICP-MS technique (mass spectrometry coupled with inductively coupled plasma-Perkin Elmer Sciex Elan 9000).

The ash mineral composition was determined by X-ray diffraction using model X'Pert Pro MPD (multi-purpose diffractometer) PW3040/60 X-ray diffractometer of the PANalytical company. Measurement conditions are power supply for the lamp: $40 \mathrm{kV}$ voltage, $40 \mathrm{~mA}$ current, analysis range from $3^{\circ}$ to $75^{\circ} 2 \Theta$, meter stroke $0.01^{\circ} \Theta$ and pulse count time-100 s. Estimated mineral content in ash samples was determined using the Rietveld method. Ash morphology and phase composition were identified with the use of scanning electron microscope PHILIPS XL 30 equipped with EDS adapter (EDAX Sapphire type).

Elementary CHNSO FlashSmart series analyser (Thermo Scientific) was used for analyses of carbon (C), hydrogen $(\mathrm{H})$, nitrogen $(\mathrm{N})$, sulphur $(\mathrm{S})$, and oxygen $(\mathrm{O})$ content in tested wood biomass samples. The chlorine content $(\mathrm{Cl})$ was determined using the Variomicro CHNS elementary analyser.

Weight method in accordance with PN-EN ISO 18,122:2016-06 was used to determined ash content (A). Total moisture content (W) in selected wood species was determined using the oven-drying method in accordance with PN-EN ISO 18,134-2:2017-03. The content of volatile parts $\left(\mathrm{V}^{\mathrm{daf}}\right)$ was determined using the weight method in accordance with PN-EN ISO 18,123:2016-01 and the calorific value $(\mathrm{Q})$ was calculated in accordance with $\mathrm{PN}-\mathrm{EN}$ ISO 18,125:2017-07.

\section{Results and discussion}

\section{Grain distribution in ashes}

What follows from the grain size distribution obtained in sieve ash analysis, is that the fraction smaller than $100 \mu \mathrm{m}$ (min. $67.4 \%$ by weight-max. $83.5 \%$ by weight) is the largest
Table 2 Percentage of the ash fraction (wt.\%)

\begin{tabular}{|c|c|c|c|c|c|c|c|}
\hline \multirow[t]{2}{*}{ Ash fraction } & \multicolumn{7}{|c|}{ Sample code } \\
\hline & $1 \mathrm{~A}$ & $2 \mathrm{~A}$ & $3 \mathrm{~A}$ & $4 \mathrm{~A}$ & $5 \mathrm{~A}$ & $6 \mathrm{~A}$ & 7A \\
\hline \multirow[t]{2}{*}{$<100 \mu \mathrm{m}$} & 79.2 & 81.3 & 83.5 & 77.8 & 67.4 & 80.9 & 100.0 \\
\hline & $1 \mathrm{~B}$ & $2 \mathrm{~B}$ & $3 \mathrm{~B}$ & $4 \mathrm{~B}$ & $5 \mathrm{~B}$ & $6 \mathrm{~B}$ & - \\
\hline$>100 \mu \mathrm{m}$ & 20.8 & 18.7 & 16.5 & 22.2 & 32.6 & 19.1 & - \\
\hline
\end{tabular}


one, and the fraction above $100 \mu \mathrm{m}$ (min. $16.5 \%$ by weight to max. $32.6 \%$ by weight) is smaller (Table 2).

Granulometric analysis using the Analysette 22 Micro Tec analyser yielded a slightly larger percentage share of ashes with a fraction lower than $100 \mu \mathrm{m}$, at a level of ca. $84 \%$ in ashes from seasoned and fresh birch. Ashes from the combustion of wood briquette are characterised by the finest grain size of all analysed wood ash samples. Compared to the other ashes, a lower content of fractions below $100 \mu \mathrm{m}$ $(67.4 \%)$ was recorded in the grain composition of ash from the combustion of mixed wood $(5 \mathrm{~A})$.

\section{Basic biomass components and calorific value}

Wood biomass is characterised by very high volatile parts content (min. 69.3 and max. 81\%), with a lower value determined for fresh birch (69.3\%) (Table 3). According to Vassilev et al. (2010), mean volatile part content in biomass does not exceed $78 \%$.

Samples of fresh birch (18.3\%) and briquette (10.7\%) exhibited the highest ash content (Table 3). High ash content in fresh birch is due to high moisture content (26.7\%), which affects wood's calorific value $(14.9 \mathrm{MJ} / \mathrm{kg})$. The ash content in firewood residues usually ranges between 0.1 and 16.5\% (Rybak 2006; Vassilev et.al. 2010; Jagustyn et al. 2011). The wood is usually not available in dry state but exhibits varying humidity levels, which can range from 15 to $60 \%$, depending on how long it has been seasoned in open air. Such a high water content in fuel results from the porosity and hygroscopicity of the wood and its structure (macroporosity) and chemical composition, mainly the presence of cellulose, hemicellulose, and lignin (microporosity). Especially soft deciduous trees are characterised by about 50\% humidity in fresh wood (Bębenek 2008). The moisture content in wood-derived biomass ranges from 13.7 to $46.7 \%$, with the highest moisture content recorded for fresh birch (Table 3 ).

Sulphur and nitrogen constitute undesirable components in biomass due to their harmful impact on the environment. The lowest $\mathrm{S}$ content $(0.11 \%)$ was found in seasoned birch, in other wood biomass samples, the sulphur content varied between 0.71 and $0.96 \%$. Zając et al. (2018) determined sulphur content in ash from the burning of deciduous wood and they found it was in the range from $5631 \mathrm{ppm}$ (birch) to $5107 \mathrm{ppm}$ (oak) whereas in pine ash it was $7142 \mathrm{ppm}$. Higher values of nitrogen $(0.32 \%)$ were discovered in wood briquettes when compared to other samples of the tested samples (Table 3).

Table 4 presents the content of basic elements in ash. A high percentage share of $\mathrm{Ca}, \mathrm{K}, \mathrm{P}, \mathrm{Al}, \mathrm{Si}$, and $\mathrm{Fe}$ was discovered in samples of wood biomass ash. The highest concentrations of these elements were found in the ash fraction below $100 \mu \mathrm{m}$. The tested wood biomass ash samples were characterised by high Fe content ranging from 5.28 to $17.74 \%$. Higher Fe concentrations were found in ash from fresh and seasoned birch and mixed deciduous wood (birch, beech, and oak). Such a high Fe content may result from soil contamination in highly urbanised areas (Silesian Voivodeship) from which wood for combustion was sourced. Such high iron content may also be a result of wood transport and processing. According to various authors (Cuenca et al. 2013; Yeboah et al. 2014; Vassilev et al. 2014), ashes from wood biomass contain $0.09-1.32 \%$ of $\mathrm{Fe}\left(\mathrm{Fe}_{2} \mathrm{O}_{3}\right)$. Higher concentrations of $\mathrm{Fe}\left(\mathrm{Fe}_{2} \mathrm{O}_{3}\right.$ ranging from 3.9 to $8.89 \%$ ) in wood biomass ash were determined, among others, by Wang et al. (2008), Koukouzas et al. (2009), and Jukić et al. (2017). Zając et al. (2018) determined Fe content in wood biomass ash at a level of 6518 ppm (birch), 9256 ppm (oak), and 3665 ppm (pine). These authors point that the bark of deciduous trees

Table 3 Basic parameters of wood biomass

\begin{tabular}{|c|c|c|c|c|c|c|c|}
\hline \multirow[t]{2}{*}{ Parameter } & \multicolumn{7}{|c|}{ Type of wood biomass } \\
\hline & Seasoned birch & Fresh birch & Seasoned alder & Seasoned beech & Seasoned oak & Seasoned spruce & $\begin{array}{l}\text { Wood } \\
\text { sawdust } \\
\text { briquette }\end{array}$ \\
\hline $\mathrm{W}(\%)$ & 15.1 & 26.7 & 16.8 & 20.2 & 18.3 & 18.6 & 13.7 \\
\hline $\mathrm{A}(\%)$ & 2.6 & 18.3 & 7.7 & 14.3 & 14.8 & 16.8 & 10.7 \\
\hline $\mathrm{Q}(\mathrm{MJ} / \mathrm{kg})$ & 16.8 & 14.9 & 15.0 & 13.6 & 15.3 & 16.3 & 17.4 \\
\hline $\mathrm{V}^{\mathrm{daf}}(\%)$ & 76.0 & 69.3 & 77.0 & 72.4 & 73.1 & 81.2 & 81.0 \\
\hline $\mathrm{C}(\%)$ & 45.8 & 40.2 & 42.9 & 43.8 & 43.7 & 44.2 & 43.7 \\
\hline $\mathrm{O}(\%))$ & 46.2 & 50.4 & 49.2 & 50.2 & 48.8 & 46.2 & 46.5 \\
\hline $\mathrm{H}(\%)$ & 5.1 & 5.2 & 4.8 & 3.7 & 4.9 & 5.3 & 6.1 \\
\hline $\mathrm{N}(\%)$ & 0.12 & 0.15 & 0.18 & 0.12 & 0.11 & 0.15 & 0.32 \\
\hline $\mathrm{S}(\%)$ & 0.11 & 0.71 & 0.89 & 0.75 & 0.45 & 0.82 & 0.96 \\
\hline $\mathrm{Cl}(\%)$ & 0.01 & 0.03 & 0.05 & 0.02 & 0.01 & 0.02 & 0.09 \\
\hline
\end{tabular}


Table 4 Composition of wood biomass ashes

\begin{tabular}{llrlllllllll}
\hline Sample code & Ca & \multicolumn{1}{l}{$\mathrm{K}$} & $\mathrm{Na}$ & $\mathrm{Mg}$ & $\mathrm{P}$ & $\mathrm{Al}$ & $\mathrm{Si}$ & $\mathrm{Mn}$ & $\mathrm{Fe}$ & $\mathrm{Ba}$ & $\mathrm{Ti}$ \\
& wt. \% & & & & & & & & & & \\
\hline 1A & 16.96 & 13.15 & 0.11 & 1.87 & 2.76 & 3.67 & 12.31 & 1.12 & 5.47 & 0.48 & 0.16 \\
1B & 9.32 & 9.21 & 0.22 & 0.85 & 2.23 & 2.87 & 13.06 & 0.02 & 3.81 & 0.2 & 0.09 \\
Totality & 26.28 & 22.36 & 0.33 & 2.72 & 4.99 & 6.54 & 25.37 & 1.14 & 9.28 & 0.68 & 0.25 \\
2A & 19.32 & 6.82 & 0.22 & 1.33 & 3.27 & 4.21 & 14.34 & 1.30 & 11.63 & 0.43 & 0.22 \\
2B & 6.68 & 4.17 & 0.21 & 1.02 & 3.44 & 3.27 & 12.39 & 0.04 & 3.27 & 0.1 & 0.14 \\
Totality & 26.0 & 10.99 & 0.43 & 1.35 & 6.71 & 7.48 & 26.73 & 1.34 & 14.9 & 0.53 & 0.36 \\
3A & 20.07 & 5.66 & 0.35 & 2.06 & 3.16 & 2.71 & 12.65 & 0.58 & 11.12 & 0.58 & 0.16 \\
3B & 12.14 & 1.43 & 0.31 & 2.28 & 3.98 & 2.26 & 11.34 & 0.02 & 6.62 & 0.22 & 0.07 \\
Totality & 32.21 & 7.09 & 0.66 & 4.34 & 7.14 & 4.97 & 23.99 & 0.6 & 17.74 & 0.8 & 0.23 \\
4A & 13.86 & 7.34 & 0.18 & 1.09 & 5.18 & 3.05 & 14.06 & 1.14 & 3.29 & 0.83 & 0.18 \\
4B & 14.95 & 5.92 & 0.24 & 1.07 & 5.92 & 3.88 & 14.67 & 0.09 & 2.42 & 0.39 & 0.1 \\
Totality & 28.81 & 13.26 & 0.42 & 2.16 & 11.1 & 6.93 & 28.73 & 1.23 & 5.71 & 1.22 & 0.28 \\
5A & 10.03 & 10.83 & 0.24 & 1.06 & 1.11 & 2.45 & 13.46 & 0.31 & 7.13 & 0.02 & 0.13 \\
5B & 10.95 & 12.72 & 0.39 & 1.12 & 2.19 & 3.16 & 14.12 & 0.16 & 8.26 & 0.01 & 0.09 \\
Totality & 20.98 & 23.55 & 0.63 & 2.18 & 3.3 & 5.61 & 27.58 & 0.47 & 15.39 & 0.03 & 0.22 \\
6A & 18.33 & 8.14 & 2.19 & 1.12 & 2.87 & 3.27 & 12.49 & 1.17 & 3.28 & 0.12 & 0.18 \\
6B & 12.56 & 9.52 & 0.21 & 1.42 & 2.67 & 3.12 & 13.42 & 0.26 & 4.46 & 0.05 & 0.06 \\
Totality & 30.89 & 16.66 & 2.4 & 2.54 & 5.54 & 6.39 & 25.91 & 1.43 & 7.74 & 0.17 & 0.24 \\
7A & 42.96 & 11.13 & 3.42 & 5.63 & 5.26 & 5.05 & 20.68 & 0.02 & 5.28 & 0.11 & 0.37 \\
\hline
\end{tabular}

contains lower Fe concentrations (birch—4560 ppm and oak-3841 ppm).

In the tested ash samples of wood biomass, higher concentrations of $\mathrm{Ca}, \mathrm{Na}, \mathrm{Mg}, \mathrm{P}, \mathrm{Fe}$, and $\mathrm{Ba}$ were found in fresh birch ash as compared to seasoned birch ash (Table 4). This mainly concerns ash fraction below $100 \mu \mathrm{m}$.

In wood briquette ash, the highest content of volatile parts (81\%), $\mathrm{Na}(5.63 \%)$, and $\mathrm{P}(5.26 \%)$ was found in comparison with the other tested ash samples. Jukić et al. (2017), Cuenca et al. (2013), and Koukouzas et al. (2009) determined Na content in wood biomass and found it to range between 0.16 and $2.05 \%\left(\mathrm{Na}_{2} \mathrm{O}\right)$, whereas $\mathrm{P}$ content ranged from 1.03 to $3.40 \%\left(\mathrm{P}_{2} \mathrm{O}_{5}\right)$.

The highest $\mathrm{K}$ content was determined in samples of alder (22.36\%), birch, oak, and beech (23.55\%) (samples 5A and $5 \mathrm{~B})$. The $\mathrm{K}$ content in other ash samples tested was in the range between $7.09 \%$ (samples $3 \mathrm{~A}$ and $3 \mathrm{~B}$ ) and $16.66 \%$ (samples 6A and 6B). According to Vassilev et al. (2010), the average $\mathrm{K}_{2} \mathrm{O}$ content in ash from wood biomass and wood combustion is $10.75 \%$. Ban and Ramli (2011) determined $\mathrm{K}_{2} \mathrm{O}$ content in ash from wood combustion and found that it was $1.1 \%$. The lowest potassium values were reported by Kowalkowski and Olejarski (2013) in birch ash (0.003\%) and spruce ash $(0.03 \%)$. Czech et al. (2018b, a) found a high content of alkaline metals ( $\mathrm{K}$ and Na) in PM2.5 emitted from the combustion of birch and softwood pellets. Higher $\mathrm{Na}$ content in the finer fraction of the examined ashes confirms this hypothesis. When it comes to K content, its share differs slightly depending on ash granulation.
The Mn concentration in the ash samples varies between 0.02 and $1.47 \%$. The top concentration of $\mathrm{Mn}$ was found in the ash fraction below $100 \mu \mathrm{m}$. Cuenca et al (2013) and Wang et al (2008) determined Mn content in wood biomass as being in the range $0.1-0.12 \%$. According to Ciesielczuk et al. (2011), hardwood ash is characterised by high concentrations of Mn (beech-45,193 mg/kg; oak-5462 mg/ $\mathrm{kg})$, similarly as pine ash $(\mathrm{Mn}-308,545 \mathrm{mg} / \mathrm{kg})$ and spruce ash do (7630 mg/kg). Jakubus and Tatuśko (2016) analysed ashes from combustion of wood and found Mn content of 1088 ppm. Symanowicz et al. (2018) determined Mn content in birch ashes at the level of $919.2 \mathrm{mg} / \mathrm{kg}$, in beech at $840.2 \mathrm{mg} / \mathrm{kg}$, alder at $421.5 \mathrm{mg} / \mathrm{kg}$, and spruce at $945.7 \mathrm{mg} /$ $\mathrm{kg}$.

The concentration of $\mathrm{Ba}$ in the analysed ash samples ranged from $0.03 \%$ (samples $5 \mathrm{~A}$ and $5 \mathrm{~B}$ ) to $1.22 \%$ (samples 4A and 4B). According to Lanzertorfer (2015), Ba concentration in ash from mixed leafy and coniferous biomass ranges between 0.009 and $0.048 \%$. According to UliaszBocheńczyk and Mokrzycki (2018), Ba content in birch ash is $0.009 \%$ and that of oak ash is $0.001 \%$. Higher Ba content in the tested ash samples may be due to soil contamination in the areas where the trees for combustion were sourced and to precipitation (hard coal combustion in the power industry and domestic furnaces).

The Ti content in wood biomass ash was found to range from 0.22 to $0.37 \%$ (Table 4). Higher concentration of this element was found in ash samples from burning briquette and seasoned birch. According to data found in the literature, 
$\mathrm{TiO}_{2}$ content in wood ash ranges between 0.35 and $0.78 \%$

(Wang et al. 2008; Cuenca et al. 2013; Jukić et al. 2017).

\section{Potentially toxic elements in wood biomass and ashes from its combustion}

Concentrations of potentially toxic elements $(\mathrm{Pb}, \mathrm{Cd}, \mathrm{Zn}, \mathrm{Ni}$, $\mathrm{Cu}, \mathrm{As}, \mathrm{Hg}$ and $\mathrm{Cr}$ ) in the tested ash samples vary greatly (Table 5). The highest $\mathrm{Pb}$ contents were found in ash with a fraction below $100 \mu \mathrm{m}$, in samples 3A $(1640 \mathrm{mg} / \mathrm{kg})$ and $5 \mathrm{~A}$ $(1198 \mathrm{mg} / \mathrm{kg}$ ). Szwalec et al. (2016) report a Pb content of $0.40 \mathrm{mg} / \mathrm{kg}$ d.m. in wood briquette. In samples of ash in this fraction $(3 \mathrm{~A}, 5 \mathrm{~A}$, and $6 \mathrm{~A})$, the maximum $\mathrm{Zn}$ contents were found, at a level of $1878 \mathrm{mg} / \mathrm{kg}, 1845 \mathrm{mg} / \mathrm{kg}$, and $1216 \mathrm{mg} /$ $\mathrm{kg}$, respectively (Wiinikka et al. 2013; Szwalec et al. 2016). Such high values are probably due to the combustion of birch with bark enriched with this element. However, the study by Zając et al. (2018) does not confirm these finding as they found lower $\mathrm{Zn}$ content who in birch and oak bark compared to wood coming from these trees. $6 \mathrm{~A}$ and $7 \mathrm{~A}$ ash samples exhibit higher concentration of As (56-61 mg/kg) compared to the other samples analysed $(11-38 \mathrm{mg} / \mathrm{kg})$. Higher concentration of Cd was also found in $3 \mathrm{~A}(9.6 \mathrm{mg} / \mathrm{kg})$ and $7 \mathrm{~A}$ samples $(11.2 \mathrm{mg} / \mathrm{kg})$, whereas samples $1 \mathrm{~A}$ and $7 \mathrm{~A}(2.1 \mathrm{mg} /$ $\mathrm{kg})$ and $4 \mathrm{~A}(1.8 \mathrm{mg} / \mathrm{kg})$ exhibited high $\mathrm{Hg}$ contents. Wisz and Matwiejew (2005) concluded that cadmium content in wood briquette ranged between 0.07 and $0.36 \mathrm{mg} / \mathrm{kg}$.

In the ash fraction above $100 \mu \mathrm{m}$, the content of potentially toxic elements was significantly lower, except for sample 5B where $\mathrm{Pb}$ was determined at $1112 \mathrm{mg} / \mathrm{kg}$. This is mainly due to the ash granulation, and probably also due to the composition of the wood briquette, which consists of waste deciduous wood (beech and oak account for 85\%) and coniferous wood (pine chips-15\%). The briquette production processes may also matter.

In the tested ash samples, $\mathrm{Ni}$ content varied only slightly when ash granulation is taken into account. The highest $\mathrm{Ni}$ content was found in samples $2 \mathrm{~A}(76 \mathrm{mg} / \mathrm{kg})$ and 7A. According to Kajda-Szcześniak (2014), the highest Ni content was found in ash from the combustion of beech $(187.2 \mathrm{mg} / \mathrm{kg})$ and pine $(36.98 \mathrm{mg} / \mathrm{kg})$. According to Symanowicz et al. (2018), Ni in ash from wood combustion ranges from $32.8 \mathrm{mg} / \mathrm{kg}$ (oak) to $91.3 \mathrm{mg} / \mathrm{kg}$ (birch). Data from subject literature are characterised by high variability of potentially toxic elements in wood biomass ash (Table 5).

Concentrations of potentially toxic elements in biomass samples before combustion can be written as follows: $\mathrm{Zn}>$ $\mathrm{Cu}>\mathrm{Pb}>\mathrm{Cd}>\mathrm{Ni}>\mathrm{Cr}>\mathrm{Hg}>$ As (Table 5). High concentrations of $\mathrm{Zn}$ and $\mathrm{Pb}$ were found in samples of biomass from fresh birch and a mixture of deciduous trees (beech, alder, and oak). $\mathrm{Zn}$ content in these samples was found to range from $55.7 \mathrm{mg} / \mathrm{kg}$ to $58.1 \mathrm{mg} / \mathrm{kg}$ and $\mathrm{Pb}$ concentration from 3.62 to $4.11 \mathrm{mg} / \mathrm{kg}$.

The PN-EN ISO 17,225-2-6:2014-07 standard can be used for the assessment of biomass quality with respect to trace elements content. It is a standard developed based on studies of different biomass types conducted in Sweden, Finland, Denmark, the Netherlands, and Germany, providing

Table 5 Potentially toxic elements ( $\mathrm{mg} / \mathrm{kg}$ ) in wood combustion ashes (WA) and in wood biomass (WB)

\begin{tabular}{|c|c|c|c|c|c|c|c|c|c|c|c|c|c|c|c|}
\hline \multirow{2}{*}{\multicolumn{2}{|c|}{$\begin{array}{l}\text { Element } \\
\text { determined } \\
\text { in the } \\
\text { sample }\end{array}$}} & \multicolumn{13}{|c|}{ Sample code } & \multirow[t]{2}{*}{ Literature data ${ }^{1}(\mathrm{WA})$} \\
\hline & & $1 \mathrm{~A}$ & 1B & $2 \mathrm{~A}$ & $2 \mathrm{~B}$ & $3 \mathrm{~A}$ & $3 \mathrm{~B}$ & $4 \mathrm{~A}$ & $4 \mathrm{~B}$ & $5 \mathrm{~A}$ & $5 \mathrm{~B}$ & $6 \mathrm{~A}$ & $6 \mathrm{~B}$ & $7 \mathrm{~A}$ & \\
\hline WA & \multirow[t]{2}{*}{$\mathrm{Pb}$} & 122 & 67 & 365 & 164 & 640 & 145 & 38 & 26 & 198 & 112 & 23 & 18 & 297 & \multirow[t]{2}{*}{$0.682-130$} \\
\hline WB & & 0.72 & & 0.98 & & 3.62 & & 0.12 & & 4.11 & & 0.11 & & 0.86 & \\
\hline WA & \multirow[t]{2}{*}{$\mathrm{Cd}$} & 3.4 & 2.5 & 4.2 & 3.3 & 9.6 & 3.1 & 1.5 & 0.8 & 3.5 & 2.1 & 2.9 & 1.8 & 11.2 & \multirow[t]{2}{*}{$0.109-31$} \\
\hline WB & & 0.21 & & 0.35 & & 0.41 & & 0.31 & & 0.22 & & 0.15 & & 0.53 & \\
\hline WA & \multirow[t]{2}{*}{$\mathrm{Zn}$} & 302 & 16 & 281 & 31 & 878 & 44 & 494 & 93 & 845 & 102 & 606 & 89 & 54 & \multirow[t]{2}{*}{$18.4-2800$} \\
\hline WB & & 21.6 & & 13.6 & & 55.7 & & 24.9 & & 58.1 & & 46.7 & & 11.5 & \\
\hline WA & \multirow[t]{2}{*}{$\mathrm{Cu}$} & 49 & 0.51 & 17 & 0.6 & 3.4 & 0.7 & 196 & 23 & 207 & 28 & 145 & 17 & 2.1 & \multirow[t]{2}{*}{$71.4-440$} \\
\hline WB & & 1.59 & & 1.88 & & 0.2 & & 2.85 & & 3.06 & & 2.18 & & 0.7 & \\
\hline WA & \multirow[t]{2}{*}{$\mathrm{Ni}$} & 43 & 32 & 76 & 43 & 43 & 40 & 25 & 24 & 33 & 31 & 38 & 32 & 67 & \multirow[t]{2}{*}{$12-500$} \\
\hline WB & & 0.2 & & 0.28 & & 0.18 & & 0.16 & & 0.17 & & 0.2 & & 0.32 & \\
\hline WA & \multirow[t]{2}{*}{ As } & 27 & 11 & 19 & 14 & 38 & 26 & 31 & 17 & 23 & 11 & 56 & 28 & 61 & \multirow[t]{2}{*}{$0.09-74$} \\
\hline WB & & bdl & & bdl & & bdl & & 0.06 & & bdl & & 0.08 & & 0.09 & \\
\hline WA & \multirow[t]{2}{*}{$\mathrm{Hg}$} & 2.1 & 1.9 & 0.9 & 0.7 & 0.8 & 0.4 & 1.8 & 1.1 & 0.7 & 0.3 & 0.1 & 0.1 & 2.1 & \multirow[t]{2}{*}{$0.06-1.2$} \\
\hline WB & & 0.007 & & 0.011 & & 0.008 & & 0.008 & & 0.1 & & bdl & & 0.007 & \\
\hline WA & \multirow[t]{2}{*}{$\mathrm{Cr}$} & 66 & 43 & 47 & 41 & 25 & 17 & 31 & 18 & 31 & 20 & 28 & 21 & 64 & \multirow[t]{2}{*}{$14-260$} \\
\hline WB & & 1.4 & & 2.2 & & 1.1 & & 0.9 & & 1.1 & & 1.4 & & 1.6 & \\
\hline
\end{tabular}

\footnotetext{
${ }^{1}$ Supancic et al. 2014; Vassilev et al. 2014; Maresca et al. 2017;Symanowicz et al. 2018
} 
reference values (typical) and occurrence ranges for particular elements. The determined concentrations of potentially toxic elements in wood biomass exceeded those typical of these biomass types found in the above-mentioned standard.

\section{Relative enrichment factor (REF) in potentially toxic elements for ashes}

The enrichment factor allows determining the accumulation of selected elements in ash from wood biomass. This value is characteristic of the specific test area from which the wood biomass samples were taken. The relative enrichment factor (REF) was calculated based on Meij's formula (1994), which takes into account the content of a specific element in the biomass ash $\left(\mathrm{C}^{\mathrm{M}}{ }_{\text {ash }}\right)$, the content of this element in biomass $\left(\mathrm{C}^{\mathrm{M}}{ }_{\mathrm{b}}\right)$ and ash content $(\mathrm{A})$ :

$\mathrm{REF}=C_{\mathrm{ash}}^{M} \times \mathrm{AIC}_{b}^{M} \times 100$.

The REF calculation results are presented in Fig. 1.

Ashes from wood biomass combustion are enriched with potentially toxic elements to varying degrees. In wood biomass ash samples, the calculated REFs are high for $\mathrm{Pb}, \mathrm{Ni}$, and $\mathrm{Hg}$ (Fig. 1). These are ashes from the combustion of fresh birch, mixed deciduous and/or coniferous wood, and wood briquette. In these samples, the REF values are at a similar level. For Ni, the REF values are similar in wood biomass ash samples with fractions both below $100 \mu \mathrm{m}$ and above $100 \mu \mathrm{m}$. The highest REF value was calculated for As in ash from burning a mixture of deciduous wood (alder and oak), deciduous and coniferous wood (beech and spruce), and wood briquette. In the remaining wood samples, As content was not determined (Table 5). Significantly lower REF values (2-10) were calculated for the remaining elements $(\mathrm{Cd}, \mathrm{Zn}$, $\mathrm{Cr}$, and $\mathrm{Cu}$ ) (Fig. 1). $\mathrm{Zn}$ and $\mathrm{Cu}$ are remarkable as for them REF values are significantly lower in the ash fraction above $100 \mu \mathrm{m}$, compared to the ash fraction below $100 \mu \mathrm{m}$.

\section{Estimated emissions of $\mathrm{Pb}, \mathrm{Cd}, \mathrm{Hg}$, and $\mathrm{As}$ from burning wood in a closed furnace}

Reduction of emissions of potentially toxic elements is one of the fundamental elements of EU environmental policy. Determination of the amount of potentially toxic pollutants emitted to the atmosphere is of great importance for measures taken to improve air quality (Maenhaut et al. 2012; Martin et al. 2013; Cincinelli et al. 2019). Wood-fired furnaces found in individual households, similarly to hard coalfired furnaces, are point sources of atmospheric pollution. Households mostly emit them during the winter season.

The amount of emissions introduced into the atmosphere depends on the type of fuel, consumption, and fuel parameters. For the calculation of $\mathrm{Pb}, \mathrm{Cd}, \mathrm{Hg}$, and As emissions from wood combustion, we used the data of the National Centre for Balancing and Management of Emissions (KOBIZE) in Poland for the year 2019, adopting the emission factor for wood determined in accordance with the recommendations of the European Environment Agency (EEA Report 2019).

Emission volume (E) was calculated per unit of energy (1 GJ) based on the relationship including which wood consumption (B), wood calorific value $\left(\mathrm{W}_{0}\right)$, and emission factor $(\mathrm{W})$ of the element in question:

$E=B \cdot W_{0} \cdot W[\mathrm{mg} / \mathrm{GJ}]$.

Table 6 presents the calculated factors of $\mathrm{Pb}, \mathrm{Cd}, \mathrm{Hg}$, and As emissions to the atmosphere after combustion of wood biomass. For calculations, we assumed $4 \mathrm{~m}^{3}$ of burnt wood and $4 \mathrm{Mg}$ of briquette. The $1 \mathrm{~m}^{3}$ weight for particular wood species, depending on the moisture content, ranged from $530 \mathrm{~kg}$ (alder) to $750 \mathrm{~kg}$ (birch).

Combustion of wood briquettes resulted in the highest emissions of lead, cadmium, mercury, and arsenic to the atmosphere. It probably results from the type of waste that is used for the production of briquettes. In this case, it included very fine sawdust generated in the process of production of wood products (deciduous and coniferous wood). Combustion of fresh and seasoned birch also results in higher, compared to other wood species, emissions of $\mathrm{Pb}, \mathrm{Cd}, \mathrm{Hg}$, and As to the atmosphere (Table 6). Studies have shown that the lowest emissions of $\mathrm{Pb}, \mathrm{Cd}, \mathrm{Hg}$, and As to the atmosphere were achieved when burning a mixture of beech and spruce. However, spruce is not wood species recommended for closed furnaces due to high resin content.

Literature data most often refer to the estimated emission of PM10 and PM2.5 to the atmosphere from wood combustion. According to a study by Czech et al. (2018b, a), PM2.5 emitted from birch combustion is enriched with $\mathrm{Zn}$ and the average emission factor is $0.683 \mu \mathrm{g} / \mathrm{GJ}$. Research conducted by Schmidl et al. (2007) indicates that emissions from the combustion of pellets and wood chips in manually loaded wood-fired furnaces amount to $0.09 \mathrm{~kg} / \mathrm{GJ}$. Kistler et al. (2012) have shown that the highest dust emissions to the atmosphere resulted from the combustion of oak $(0.22 \mathrm{~kg} /$ GJ). Trojanowski and Fthenakis (2019), in their studies on dust emissions to the atmosphere from wood combustion in residential buildings, showed that the vast majority of the formed particles fall within the nanometre (NP) range. The size of the emitted particles is influenced by the type of wood and the type of furnace (fireplace).

Wood-fired furnaces of the fireplace type that do not comply with emission standards may provide dust emissions in the range of $1350 \mathrm{mg} / \mathrm{m}^{3}$ (dry wood) to $2180 \mathrm{mg} / \mathrm{m}^{3}$ (wet wood) (Siergiej and Jędrak, 2019). Out of all the PM 2.5 dust from wood combustion, $70 \%$ comes from fireplaces and $30 \%$ 
$\mathrm{Pb}$

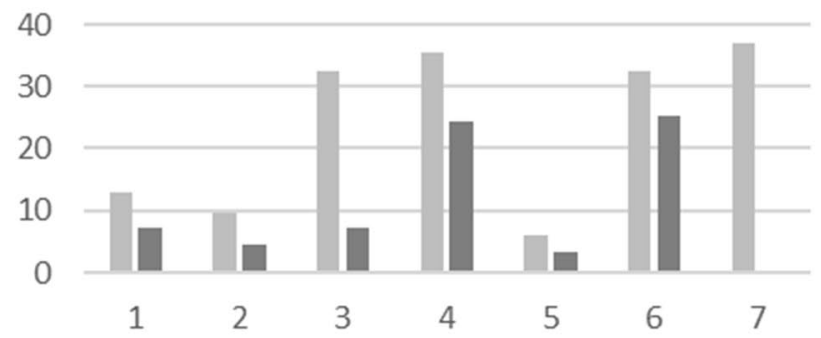

$\square \mathrm{A} \square \mathrm{B}$

Zn

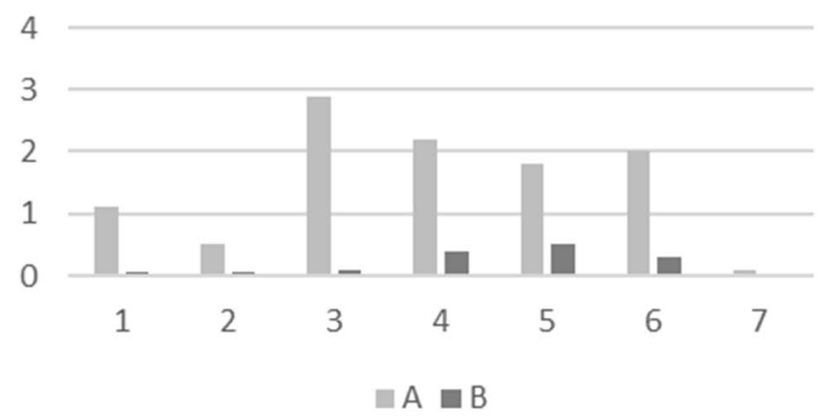

$\mathrm{Ni}$

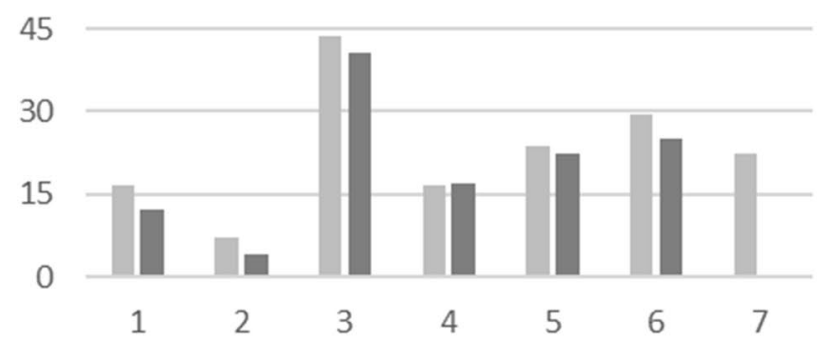

$\square \mathrm{A} \square \mathrm{B}$

$\mathrm{Hg}$

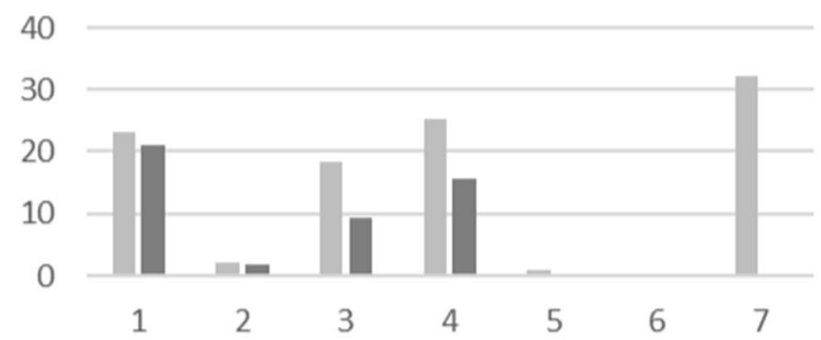

$\mathrm{A} \boxminus \mathrm{B}$
$\mathrm{Cd}$

6

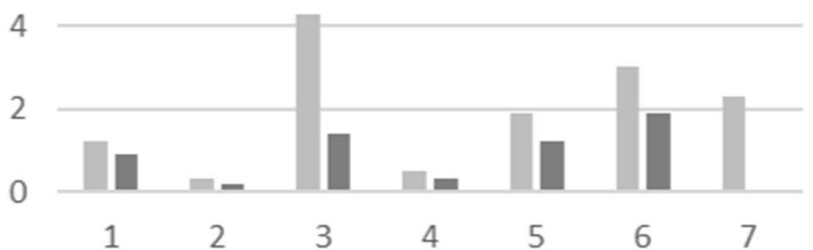

$\square \mathrm{A} \square \mathrm{B}$

$\mathrm{Cu}$

15

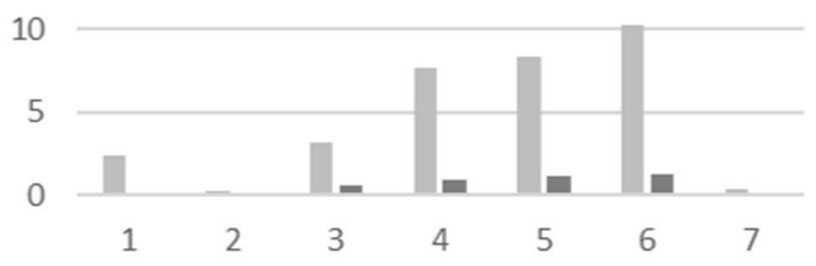

$\square \mathrm{A} \square \mathrm{B}$

As

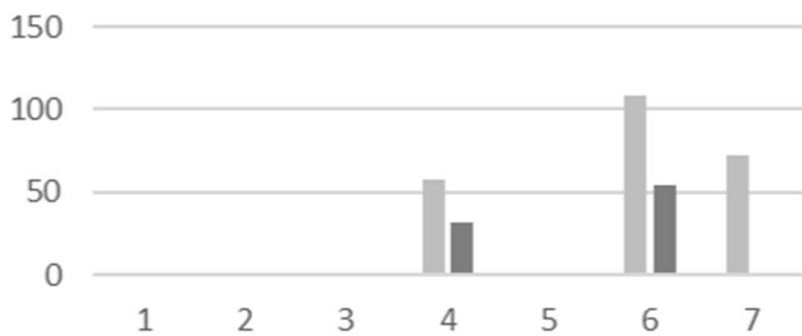

$\square \square \mathrm{B}$

$\mathrm{Cr}$

6

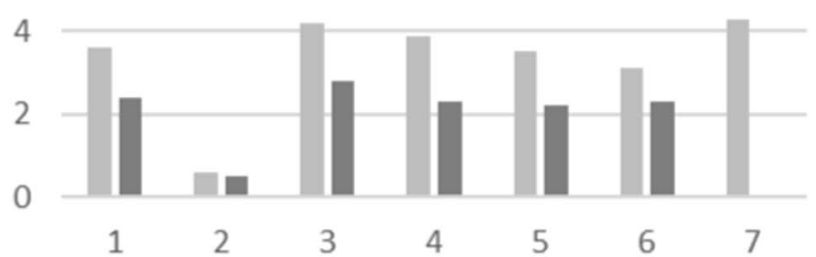

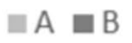

Fig. 1 Calculated $\mathrm{REF}_{\mathrm{s}}$ values in ashes from wood biomass 
Table 6 The value of emissions (mg) of some elements from the combustion of wood and its products in closed furnaces (fireplace)

\begin{tabular}{llllrlrrr}
\hline E (mg) & $W(\mathrm{mg} / \mathrm{GJ})$ & \multicolumn{7}{l}{ Emissions to the atmosphere-analysed samples } \\
\cline { 3 - 9 } & & 1 & 2 & 3 & \multicolumn{1}{l}{4} & 5 & 6 & 7 \\
\hline $\mathrm{Pb}$ & 27 & 858.6 & 1161.2 & 1206.9 & 997 & 1037.6 & 872.8 & 1879.2 \\
$\mathrm{Cd}$ & 13 & 413.4 & 559.1 & 475.2 & 480.9 & 477.1 & 420.2 & 904.8 \\
$\mathrm{Hg}$ & 0.56 & 17.8 & 24 & 20.5 & 20.7 & 20.5 & 13.5 & 38.9 \\
$\mathrm{As}$ & 0.19 & 6 & 8.1 & 6.9 & 7 & 6.9 & 6.0 & 13.2 \\
\hline
\end{tabular}

from fired boilers (WHO 2015). Other authors (Bari et al. 2011; Amaral et al. 2016) also point to the high emission of fine particles $(<10 \mu \mathrm{m})$ to the atmosphere as a result of biomass combustion. The particulate matter emission rate from biomass combustion in residential buildings is $17.3 \mathrm{~g} /$ kg PM2.5 (Alves et al. 2011).

Wood burning can cause an increase in particulate matter concentration, which in turn causes eye irritation, affects the respiratory system, can cause heart rhythm issues, and lead to stroke (Riddervold et al. 2012; Robinson 2015; Eze et al. 2015; Morakinyo et al. 2016; Shi et al. 2016; Kasangana et al. 2017).

\section{Phase composition of wood biomass ash}

Mineral content in the tested ash samples was determined by X-ray diffraction. In all tested ash samples with the $<100 \mu \mathrm{m}$ fraction, dominant components included calcite $\left(\mathrm{CaCO}_{3}\right)$, fairchildite $\left(\mathrm{K}_{2} \mathrm{Ca}\left(\mathrm{CO}_{3}\right)_{2}\right)$, periclase $(\mathrm{MgO})$, monetite $\left(\mathrm{CaHPO}_{4}\right)$, and quartz $\left(\mathrm{SiO}_{2}\right)$. The percentage share of these minerals varies depending on the type of wood biomass burnt. Ashes from burning fresh birch (3A) and seasoned birch (2A) contain the most calcite (about 57\%) in comparison with other tested ash samples $(23 \%-37 \%)$. The estimated content of fairchildite, $(19 \%-23 \%)$ and monetite $(8 \%-16 \%)$ was higher in samples of ash from the incineration of seasoned birch (2A) and alder (1A) compared to the other ash samples.

In ashes with a fraction above $100 \mu \mathrm{m}$, the main minerals included calcite and quartz. In fresh (3B) and seasoned (2B) birch ash, calcite content was estimated at $83 \%$ and $64 \%$, respectively. Michalik and Wilczyńska-Michalik (2012) found high quartz content in beech bark ash (56\%-58\%). The share of quartz in these ash samples ranged from 25 (3B) to $32.5 \%$ (2B). Auxiliary components in the tested ashes (2B, $3 \mathrm{~B}, 4 \mathrm{~B}, 5 \mathrm{~B}, 6 \mathrm{~B})$ included periclase $(\mathrm{MgO})$, apatite $\left(\mathrm{Ca}_{5}\left(\mathrm{PO}_{4}\right.\right.$ )$_{3}(\mathrm{OH}, \mathrm{F}, \mathrm{Cl})$, sylvite $(\mathrm{KCl})$, dolomite $\left(\left[\mathrm{CaMg}\left(\mathrm{CO}_{3}\right)_{2}\right]\right)$, calcium oxide $(\mathrm{CaO})$, and portlandite $\left(\mathrm{Ca}(\mathrm{OH})_{2}\right)$.

The crystal structure models were calculated using the ICDD database. Information on the quantitative, relative content of crystalline phases (the method does not take into account the amorphous phase) was obtained based on the Rietveld method, which consists of calculating the theoretical diffractogram and fitting it, using the least-squares method, to the experimental diffractogram. The amount of the " $t$ " phase after running the Rietveld method was estimated using the following formula (Gąsiński and Poszytek, 2013):

$S_{t}=A_{t} B_{t} M_{t} V_{t} / \sum_{n} A_{n} B_{n} M_{n} V_{n}$

where

$\mathrm{S}_{t}$-weight share of the crystalline phase $s$ in the $i$-phase mixture.

$\mathrm{A}_{t}$ - phase scale factor $s$.

$\mathrm{B}_{t}$-number of formal units in the elementary cell of phase $s$.

$\mathrm{M}_{t}$-weight of the formal unit of phase $s$.

$\mathrm{V}_{t}$ - volume of the elementary cell of phase $s$.

$n$-number of modelled crystalline phases.

The content of these components calculated was estimated using the Rietveld method at less than $4 \%$. Among mineral components, calcite (93\%) and portlandite (7\%) content were determined in sample 1B (alder ash). As a soil component, quartz is very often found in ash from wood biomass (Bostrom et al. 2012; Sano et al. 2013). The high content of $\mathrm{Al}, \mathrm{K}$, and $\mathrm{Na}$ in wood biomass ash results from burning intense combustion of fossil fuels in a given area and their concentration in soil and tree bark (Sano et al., 2013). Their phytoavailability is expressed by the following relationship: $\mathrm{K}>\mathrm{Ca}>\mathrm{Mg}<\mathrm{P}$.

Ash analyses by means of scanning electron microscopy allowed us to determine the morphology and chemical composition of individual particles and ash aggregates. The monetite substance in ashes from combustion of wood biomass usually contains admixtures of $\mathrm{Mg}, \mathrm{K}$, and $\mathrm{Mn}$ in variable amounts (Fig. 2). It coexists with calcite and $\mathrm{Mg}$, $\mathrm{Mn}$, and $\mathrm{Ba}$ oxides forming openwork forms and aggregates which mutually overgrow one another. Inclusions of fairchildite and portlandite are also present in this substance.

The pores being the residue after wood combustion are usually filled with a substance consisting of iron and titanium oxides $\left(\mathrm{Fe}_{2} \mathrm{O}_{3} ; \mathrm{TiO}_{2}\right)$ and aluminosilicate substances and aggregates (Fig. 3).

The phase composition of ash from wood biomass combustion includes inorganic components, both amorphous and crystalline (Vassilev et al. 2013). Many authors (Maschio et al. 2011; Jukić et al. 2017; Maresca et al. 2017) indicate that the main components in ash from wood combustion 

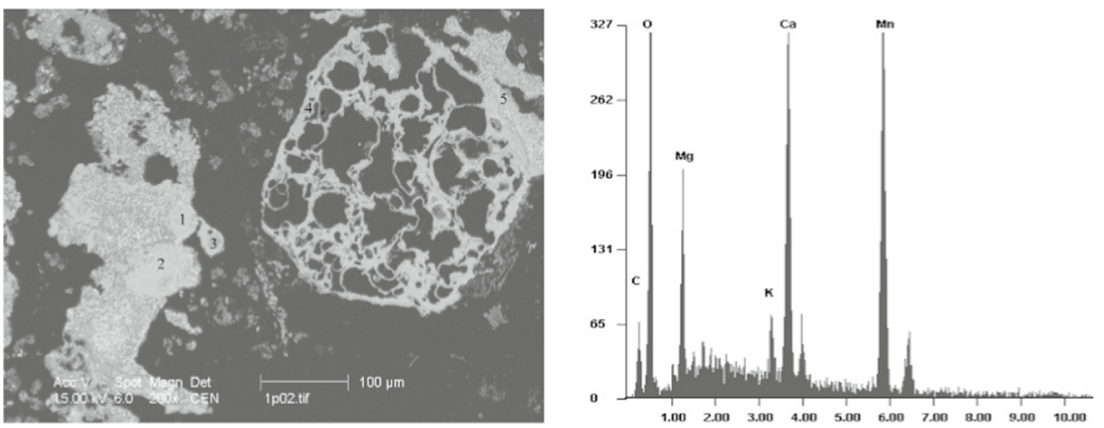

1

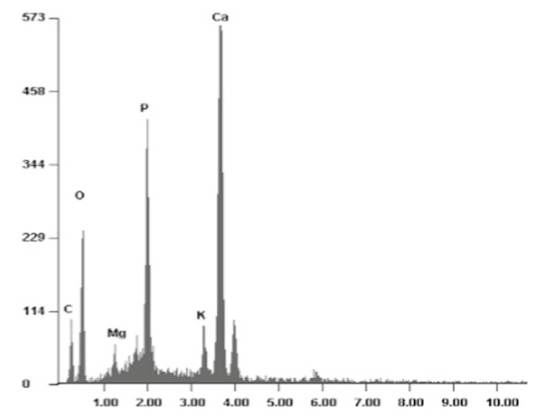

3

Fig. 2 SEM and EDS images of particles in ashes from combustion of birch seasoned at $500{ }^{\circ} \mathrm{C}$
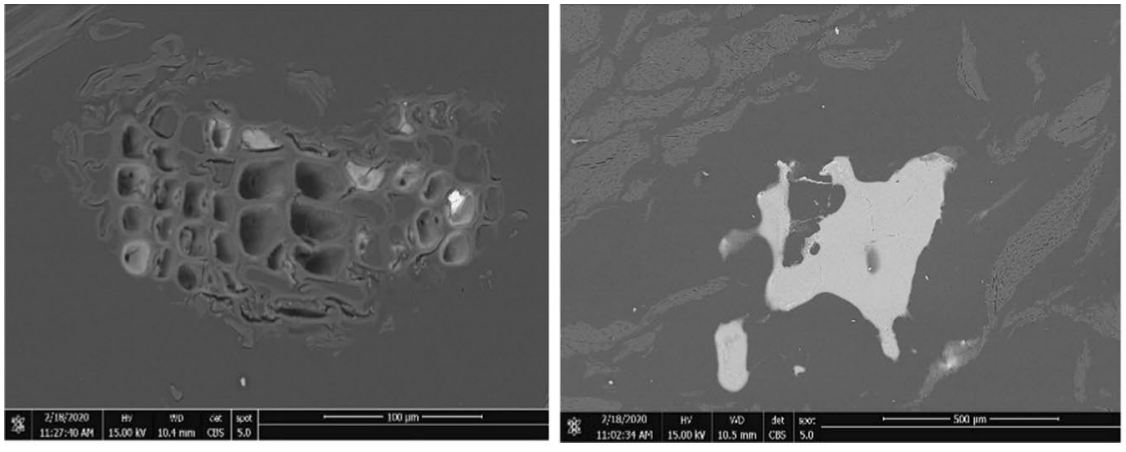

b

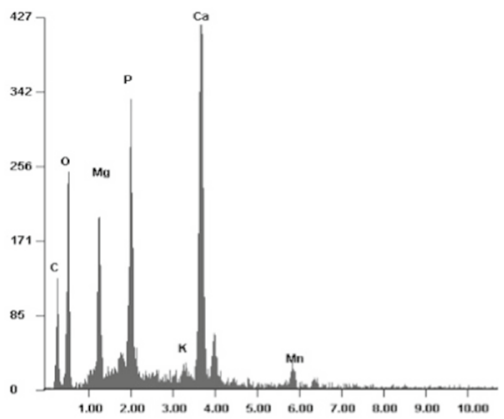

4

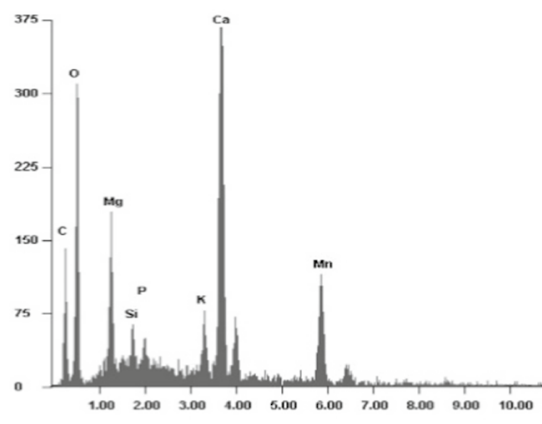

2

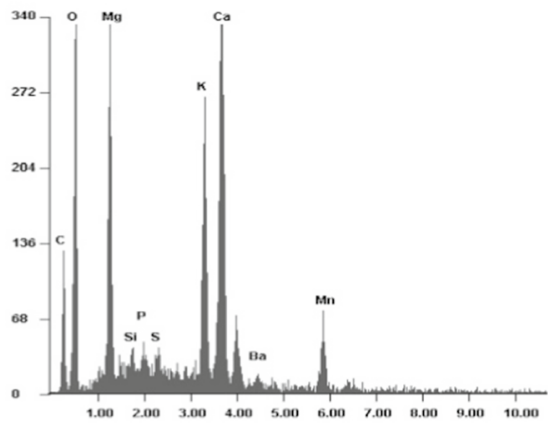

5

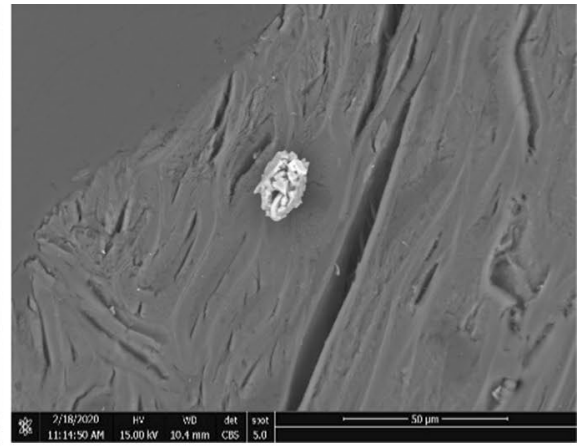

c

Fig. 3 SEM images showing phases in ash from seasoned birch combustion (a-calcite with Mn in the wood structure after burning; $\mathbf{b}-$ quartz; c_- calcite with $\mathrm{Mn}$ and $\mathrm{Ba}$ )

include quartz, calcite, periclase, and calcium oxide. Maresca et al (2017) also report the presence of hematite $\left(\mathrm{Fe}_{2} \mathrm{O}_{3}\right)$ in spruce ash.

Calcite, which is present in the fibrous wood tissues, was also observed in wood biomass (Fig. 3a). Quartz mainly fills the cavities between bark crumb and pulp (Fig. 3b). Calcite is most often found on the wood surface and contains Mn and/or Ba (Fig. 3b, c). Ashes from the combustion of wood that has a long growth period may have a different mineral composition and higher concentrations of heavy metals (Nunes et al. 2016).

\section{Statistical analysis of results}

Basic statistical parameters were calculated for the test results: coefficient of variation $(\mathrm{CV})$ and variance $(\mathrm{V})$. Using Pearson's linear correlation coefficient, an attempt was made to determine the relationship between potentially toxic elements and $\sum \mathrm{Si}+\mathrm{Al}$ and $\sum \mathrm{Ca}+\mathrm{K}$ (Table 7). The coefficient of variation, like the standard deviation, is used to investigate the degree of variation in the value of a variable. The calculated coefficient of variation in the range of $0-20 \%$ for 
Table 7 Values of Pearson correlation coefficients for potentially toxic elements calculated concerning $\sum \mathrm{Ca}+\mathrm{K}$ and $\sum \mathrm{Si}+\mathrm{Al}$, and statistical parameters in wood ashes $(\mathrm{n}=5)$

\begin{tabular}{|c|c|c|c|c|c|c|c|c|c|c|c|c|c|c|}
\hline Element & $\begin{array}{l}1 \mathrm{~A}+1 \mathrm{~B} \\
\sum \mathrm{Ca}+\mathrm{K}\end{array}$ & $2 \mathrm{~A}+2 \mathrm{~B}$ & $3 A+3 B$ & $4 A+4 B$ & $5 A+5 B$ & $6 A+6 B$ & $7 \mathrm{~A}$ & $\begin{array}{l}\text { 1A-1B } \\
\text { Coeffici }\end{array}$ & $\begin{array}{l}2 \mathrm{~A}-2 \mathrm{~B} \\
\text { ent of var }\end{array}$ & $\begin{array}{c}3 \mathrm{~A}-3 \mathrm{~B} \\
\text { ation }(\mathrm{CV}\end{array}$ & $4 A-4 B$ & $5 \mathrm{~A}-5 \mathrm{~B}$ & $6 \mathrm{~A}-6 \mathrm{~B}$ & $7 \mathrm{~A}$ \\
\hline $\mathrm{Pb}$ & 0.87 & 0.78 & 0.85 & 0.85 & 0.84 & 0.86 & 0.53 & $\begin{array}{l}5.38 \\
2.44\end{array}$ & $\begin{array}{l}3.78 \\
1.89\end{array}$ & $\begin{array}{l}0.98 \\
2.07\end{array}$ & $\begin{array}{l}5.69 \\
6.39\end{array}$ & $\begin{array}{l}1.04 \\
1.45\end{array}$ & $\begin{array}{l}12.8 \\
9.36\end{array}$ & 1.54 \\
\hline $\mathrm{Cd}$ & 0.81 & 0.77 & 0.89 & 0.83 & 0.88 & 0.73 & 0.24 & $\begin{array}{l}4.81 \\
10.51\end{array}$ & $\begin{array}{l}4.94 \\
4.85\end{array}$ & $\begin{array}{l}2.61 \\
4.03\end{array}$ & $\begin{array}{l}5.44 \\
4.82\end{array}$ & $\begin{array}{l}3.64 \\
7.77\end{array}$ & $\begin{array}{l}3.39 \\
5.55\end{array}$ & 2.94 \\
\hline $\mathrm{Zn}$ & 0.88 & 0.89 & 0.88 & 0.82 & 0.34 & 0.88 & 0.59 & $\begin{array}{l}1.95 \\
10.51\end{array}$ & $\begin{array}{l}2.34 \\
6.83\end{array}$ & $\begin{array}{l}0.91 \\
4.91\end{array}$ & $\begin{array}{l}0.93 \\
4.83\end{array}$ & $\begin{array}{l}0.54 \\
2.48\end{array}$ & $\begin{array}{l}1.46 \\
5.26\end{array}$ & 6.03 \\
\hline $\mathrm{Cu}$ & 0.65 & 0.77 & 0.57 & 0.60 & 0.07 & 0.84 & 0.80 & $\begin{array}{l}3.5 \\
12.09\end{array}$ & $\begin{array}{l}9.9 \\
19.86\end{array}$ & $\begin{array}{l}7.51 \\
4.91\end{array}$ & $\begin{array}{l}1.07 \\
4.5\end{array}$ & $\begin{array}{l}7.5 \\
1.99\end{array}$ & $\begin{array}{l}7.86 \\
7.82\end{array}$ & 8.23 \\
\hline $\mathrm{Ni}$ & 0.78 & 0.69 & 0.82 & 0.81 & 0.29 & 0.75 & 0.50 & $\begin{array}{l}5.85 \\
7.75\end{array}$ & $\begin{array}{l}2.23 \\
3.19\end{array}$ & $\begin{array}{l}3.97 \\
8.55\end{array}$ & $\begin{array}{l}5.27 \\
7.19\end{array}$ & $\begin{array}{l}5.85 \\
7.75\end{array}$ & $\begin{array}{l}5.46 \\
2.55\end{array}$ & 4.4 \\
\hline As & 0.39 & 0.76 & 0.89 & 0.84 & 0.73 & 0.87 & 0.00 & $\begin{array}{l}7.08 \\
15.89\end{array}$ & $\begin{array}{l}4.47 \\
6.63\end{array}$ & $\begin{array}{l}4.52 \\
8.16\end{array}$ & $\begin{array}{l}5.38 \\
10.2\end{array}$ & $\begin{array}{l}7.67 \\
15.89\end{array}$ & $\begin{array}{l}5.12 \\
6.15\end{array}$ & 3.39 \\
\hline $\mathrm{Hg}$ & 0.76 & 0.82 & 0.89 & 0.80 & 0.77 & 0.46 & 0.13 & $\begin{array}{l}3.89 \\
6.62\end{array}$ & $\begin{array}{l}10.94 \\
20.2\end{array}$ & $\begin{array}{l}13.21 \\
12.83\end{array}$ & $\begin{array}{l}7.08 \\
7.42\end{array}$ & $\begin{array}{l}11.65 \\
0.0\end{array}$ & $\begin{array}{l}0.0 \\
0.0\end{array}$ & 7.77 \\
\hline $\mathrm{Cr}$ & 0.82 & 0.14 & 0.70 & 0.65 & 0.81 & 0.53 & 0.63 & $\begin{array}{l}3.8 \\
4.08\end{array}$ & $\begin{array}{l}4.41 \\
5.27\end{array}$ & $\begin{array}{l}10.1 \\
4.8\end{array}$ & $\begin{array}{l}6.7 \\
12.0\end{array}$ & $\begin{array}{l}5.56 \\
6.3\end{array}$ & $\begin{array}{l}5.51 \\
6.0\end{array}$ & 6.38 \\
\hline Element & $\begin{array}{l}1 \mathrm{~A}+1 \mathrm{~B} \\
\sum \mathrm{Si}+\mathrm{Al}\end{array}$ & $2 \mathrm{~A}+2 \mathrm{~B}$ & $3 A+3 B$ & $4 A+4 B$ & $5 A+5 B$ & $6 A+6 B$ & $7 \mathrm{~A}$ & $\begin{array}{l}1 \mathrm{~A}-1 \mathrm{~B} \\
\text { Varianc }\end{array}$ & $\begin{array}{l}2 \mathrm{~A}-2 \mathrm{~B} \\
(\mathrm{~V})\end{array}$ & $3 \mathrm{~A}-3 \mathrm{~B}$ & $4 \mathrm{~A}-4 \mathrm{~B}$ & $5 \mathrm{~A}-5 \mathrm{~B}$ & $6 A-6 B$ & $7 \mathrm{~A}$ \\
\hline $\mathrm{Pb}$ & 0.60 & 0.35 & 0.64 & 0.62 & 0.44 & 0.74 & 0.22 & $\begin{array}{l}44.25 \\
0.03\end{array}$ & $\begin{array}{l}188.92 \\
9.67\end{array}$ & $\begin{array}{l}39.0 \\
8.92\end{array}$ & $\begin{array}{l}4.67 \\
2.92\end{array}$ & $\begin{array}{l}4.25 \\
8.25\end{array}$ & $\begin{array}{l}8.67 \\
2.92\end{array}$ & 3.92 \\
\hline $\mathrm{Cd}$ & 0.75 & 0.73 & 0.73 & 0.62 & 0.82 & 0.77 & 0.32 & $\begin{array}{l}0.03 \\
2.92\end{array}$ & $\begin{array}{l}0.04 \\
0.03\end{array}$ & $\begin{array}{l}0.06 \\
0.02\end{array}$ & $\begin{array}{l}0.01 \\
20.25\end{array}$ & $\begin{array}{l}0.02 \\
0.03\end{array}$ & $\begin{array}{l}0.01 \\
0.01\end{array}$ & 0.11 \\
\hline $\mathrm{Zn}$ & 0.77 & 0.77 & 0.39 & 0.77 & 0.03 & 0.62 & 0.49 & $\begin{array}{l}34.67 \\
2.92\end{array}$ & $\begin{array}{l}43.58 \\
4.33\end{array}$ & $\begin{array}{l}63.0 \\
4.67\end{array}$ & $\begin{array}{l}20.92 \\
20.25\end{array}$ & $\begin{array}{l}20.92 \\
6.33\end{array}$ & $\begin{array}{l}76.92 \\
21.67\end{array}$ & 10.92 \\
\hline $\mathrm{Cu}$ & 0.49 & 0.60 & 0.57 & 0.60 & 0.00 & 0.71 & 0.70 & $\begin{array}{l}2.92 \\
0.004\end{array}$ & $\begin{array}{l}2.92 \\
0.02\end{array}$ & $\begin{array}{l}0.06 \\
4.67\end{array}$ & $\begin{array}{l}4.33 \\
2.92\end{array}$ & $\begin{array}{l}16.92 \\
6.25\end{array}$ & $\begin{array}{l}124.6 \\
1.66\end{array}$ & 0.03 \\
\hline $\mathrm{Ni}$ & 0.70 & 0.66 & 0.72 & 0.72 & 0.30 & 0.79 & 0.61 & $\begin{array}{l}6.25 \\
6.25\end{array}$ & $\begin{array}{l}0.92 \\
1.67\end{array}$ & $\begin{array}{l}1.67 \\
6.92\end{array}$ & $\begin{array}{l}1.67 \\
2.92\end{array}$ & $\begin{array}{l}6.25 \\
6.25\end{array}$ & $\begin{array}{l}4.25 \\
0.67\end{array}$ & 8.67 \\
\hline As & 0.56 & 0.24 & 0.41 & 0.43 & 0.17 & 0.43 & 0.00 & $\begin{array}{l}3.58 \\
2.92\end{array}$ & $\begin{array}{l}2.92 \\
2.92\end{array}$ & $\begin{array}{l}2.92 \\
4.44\end{array}$ & $\begin{array}{l}2.92 \\
2.92\end{array}$ & $\begin{array}{l}2.92 \\
2.92\end{array}$ & $\begin{array}{l}11.58 \\
2.92\end{array}$ & 4.25 \\
\hline $\mathrm{Hg}$ & 0.49 & 0.48 & 0.45 & 0.44 & 0.38 & 0.33 & 0.00 & $\begin{array}{l}0.01 \\
0.02\end{array}$ & $\begin{array}{l}0.01 \\
0.01\end{array}$ & $\begin{array}{l}0.01 \\
0.003\end{array}$ & $\begin{array}{l}0.02 \\
0.02\end{array}$ & $\begin{array}{l}0.01 \\
0.0\end{array}$ & $\begin{array}{l}0.0 \\
0.0\end{array}$ & 0.03 \\
\hline $\mathrm{Cr}$ & 0.60 & 0.22 & 0.56 & 0.72 & 0.66 & 0.54 & 0.26 & $\begin{array}{l}6.25 \\
3.0\end{array}$ & $\begin{array}{l}4.25 \\
3.67\end{array}$ & $\begin{array}{l}6.25 \\
0.67\end{array}$ & $\begin{array}{l}4.25 \\
4.67\end{array}$ & $\begin{array}{l}2.92 \\
1.67\end{array}$ & $\begin{array}{l}2.25 \\
1.67\end{array}$ & 16.67 \\
\hline
\end{tabular}

$r=0.00-0.10 ; r=0.10-0.39 ; r=0.40-0.69 ; r=0.70-0.89$

potentially toxic elements is indicative of low variation in the chemical composition of wood ash. The calculated variance values are indicative of high variability of $\mathrm{Pb}(1 \mathrm{~A}$ and 1B), Zn (1A, 2A, 4A, 4B, 6A, 6B), and $\mathrm{Cu}(6 \mathrm{~A})$ in relation to the mean value in the tested ash samples. The correlation coefficient Pearson $(r=0.00-0.10$ negligible correlation; $r=0.10-0.39$ weak correlation; $r=0.40-0.69$ moderate correlation; $\mathrm{r}=0.70-0.89$ strong correlation; $\mathrm{r}=0.90-1.00$ very strong correlation) was used to assess the relationship between the determined elements (Schober et al. 2018). High correlation coefficients values $(r=0.70-0.89)$ were found for potentially toxic elements $(\mathrm{Pb}, \mathrm{Cd}, \mathrm{Zn}, \mathrm{Cu}, \mathrm{As}$, and $\mathrm{Ni}$ ) against $\sum \mathrm{Ca}+\mathrm{K}$. This is mainly due to the high content of alkaline components $(\mathrm{Ca}, \mathrm{K}, \mathrm{Na})$ in natural biomass.
The highest $\mathrm{Ca}$ content was found in tree bark (Mirowski et al. 2018). Moderate correlation coefficients were found for potentially toxic elements relative to the $\sum \mathrm{Si}+\mathrm{Al}$ sum. The average content of the most common oxides in the chemical composition of natural woody biomass, can be represented as follows (Vassilev et al. 2010): $\mathrm{CaO}>\mathrm{SiO}_{2}>\mathrm{K}_{2} \mathrm{O}>\mathrm{Mg}$ $\mathrm{O}>\mathrm{Al}_{2} \mathrm{O}_{3}>\mathrm{P}_{2} \mathrm{O}_{5}$. The lower concentration of $\mathrm{Si}$ and $\mathrm{Al}$ in the natural woody biomass and the investigated ash samples affects the correlation with potentially toxic elements. A large number of strong and moderate significant correlation coefficients is indicative of statistically significant relationships that exist between the determined potentially toxic elements and the concentrations of $\sum \mathrm{Ca}+\mathrm{K}$ and $\sum \mathrm{Si}+\mathrm{Al}$. 
Further research in this area, on a larger sample, is being carried out, and the results obtained will allow to draw correct conclusions and perform correct statistical calculations.

\section{Conclusion}

The type of wood, its storage time, and conditions influence the calorific value and thus on the energy efficiency during combustion and, above all, the chemical composition of the generated ash.

In the ash fraction below $100 \mu \mathrm{m}$, high contents of $\mathrm{Ca}$, $\mathrm{K}, \mathrm{Si}$, and $\mathrm{Fe}$ and potentially toxic elements were recorded. The high concentration of $\mathrm{Fe}$ in wood biomass ash is probably determined by the mineral composition of soils and the location of wood harvesting. In the phase composition of seasoned wood, we determined iron oxides, which can be found in fibrous tissues.

Relative enrichment factors $\left(\mathrm{REF}_{\mathrm{s}}\right)$ calculated for $\mathrm{As}, \mathrm{Pb}$, $\mathrm{Ni}$, and $\mathrm{Hg}$ in ashes were significantly higher compared to the other elements $(\mathrm{Cd}, \mathrm{Cu}, \mathrm{Zn}, \mathrm{Cr})$. The results obtained are indicative of the need to monitor the content of potentially toxic elements in burnt wood biomass, due to the high variability of the concentration of these elements.

The average calculated values of $\mathrm{Pb}, \mathrm{Cd}, \mathrm{Hg}$, and $\mathrm{As}$ emissions for the examined ash are the highest for the combustion of wood briquettes and the lowest for the combustion of spruce. Combustion of these wood species may contribute to the deterioration of air quality in areas where fireplace furnaces are used to heat houses.

The phase composition of ash from wood biomass is dominated by calcite, fairchildite, periclase, monetite, and quartz. Their percentage share depends on the type of wood biomass.

Further research is needed taking into account the chemical properties of wood biomass and its commercial products as additional assessment criteria.

\section{Conflicts of interest}

The authors declare no conflict of interest.

Supplementary information is available for this paper at https://doi. org/10.1007/s13762-021-03506-9.

Funding We have not received any funds.

Open Access This article is licensed under a Creative Commons Attribution 4.0 International License, which permits use, sharing, adaptation, distribution and reproduction in any medium or format, as long as you give appropriate credit to the original author(s) and the source, provide a link to the Creative Commons licence, and indicate if changes were made. The images or other third party material in this article are included in the article's Creative Commons licence, unless indicated otherwise in a credit line to the material. If material is not included in the article's Creative Commons licence and your intended use is not permitted by statutory regulation or exceeds the permitted use, you will need to obtain permission directly from the copyright holder. To view a copy of this licence, visit http://creativecommons.org/licenses/by/4.0/.

\section{References}

Alves C, Gonçalves C, Fernandes AP, Tarelho L, Pio C (2011) Fireplace and wood stove fine particle emissions from combustion of western Mediterranean wood types. Atmospheric Res 101:692700. https://doi.org/10.1016/j.atmosres.2011.04.015

Amaral SS, Carvalho JA Jr, Martins-Costa MA, Pinheiro C (2016) Particulate matter emissions factor for biomass combustion. Atmosphere 7:141. https://doi.org/10.3390/atmos7110141

Ban CC, Ramli M (2011) The implementation of wood waste ash as a partial cement replacement material in the production of structural grade concrete and mortar: An overview. Resour Conserv Recycl 55:669-685. https://doi.org/10.1016/j.resconrec.2011.02.002

Bari MA, Baumbach G, Kuch B, Scheffknecht C (2011) Air pollution in residential areas from wood-fired heating. Aerosol Air Quality Res 11:749-757. https://doi.org/10.4209/aaqr.2010.09.0079

Berra M, Mangialardi T, Paolini AE (2015) Reuse of woody biomass fly as in cement-based materials. Constr Build Mater 76:286-296. https://doi.org/10.1016/j.conbuildmat.2014.11.052

Bębenek Z (2008) Biopaliwa stałe [w:] Odnawialne i niekonwencjonalne źródła energii, Gałusza M, Paruch J (red.), Tarbonus, Kraków-Tarnobrzeg (Poland).

Bostrom D, Skoklung N, Grimm A, Boman C, Ohman M, Brostrom M, Backman R (2012) Ash transformation chemistry during combustion of biomass. Energy Fuels 26:85-93. https://doi.org/10.1021/ ef201205b

Carvalho RL, Jensen OM, Luís AC (2016) Mapping the performance of wood-burning stoves by installations worldwide. Energy Build 127:658-679. https://doi.org/10.1016/j.enbuild.2016.06.010

Czech H, Miersch T, Orasche J, Abbaszade G, Sippula O, Tissari J, Michalke B, Schnelle-Kreis J, Streibel T, Jokiniemi J, Zimmermann R (2018a) Chemical composition and speciation of particulate organic matter from modern residential small-scale wood combustion appliances. Sci Total Environ 612:636-648. https:// doi.org/10.1016/j.scitotenv.2017.08.263

Ciesielczuk T, Kusza G, Nemś A (2011) Fertilization with biomass ashes as a source of trace elements for soils. Instytut Ochrony Środowiska-Państwowy Instytut Badawczy, Warszawa, Poland. Ochrona Środowiska i Zasobów Naturalnych, vol 49, pp 219-227. ISSN 1230-7831

Cincinelli A, Guerranti C, Martellini T, Scodellini R (2019) Residential wood combustion and its impact on urban air quality in Europe. Current Opinion Environ Sci Health 8:10-14. https://doi.org/10. 1016/j.coesh.2018.12.007

Czop M, Kajda-Szcześniak M (2010) Content of heavy metals in ashes after burning biomass briquette. Archives Waste Manage Environ Protect 12(1):67-76

Czop M, Kajda-Szcześniak M (2013) Environment impact of straw based fuel combustion. Archives Waste Manage Environ Protect 39(4):71-80. https://doi.org/10.2478/aep-2013-0031

Corsini E, Vecchi R, Marabiin L, Fermo P, Becagli S, Bernardoni V, Caruso D, Corbella L, Dell'Acqua M, Galli CL, Lonati G, Ozgen S, Papale A, Signorini S, Tardivo R, Valli G, Marinovich $M$ (2017) The chemical composition of ultrafine particles and associated biological effects at an alpine town impacted by wood burning. Sci Total Environ 587-588:223-231. https://doi.org/10. 1016/j.scitotenv.2017.02.125 
Cuenca J, Rodríguez J, Martín-Morale SM, Sánchez-Roldá Z, Zamorano $M$ (2013) Effects of olive residue biomass fly ash as filler in self compacting concrete. Constr Build Mater 40:702-709. https:// doi.org/10.1016/j.conbuildmat.2012.09.101

Czech H, Miersch T, Orasche J, Abbaszade G, Sippula O, Tissari J, Michalke B, Schnelle-Kreis J, Streibel T, Jokiniemi J, Zimmermann R (2018b) Chemical composition and speciation of particulate organic matter from modern residential small-scale wood combustion appliances. Sci Total Environ 612:636-648. https:// doi.org/10.1016/j.scitotenv.2017.08.263

Daellenbach KR, Bozzetti C, Krepelová A, Canonaco F, Wolf R, Zotter P, Fermo P, Crippa M, Slowik JG, Sosedova Y, Zhang Y, Huang RJ, Poulain L, Szidat S, Baltensperger U, Haddad IE, Prévôt ASH (2016) Characterization and source apportionment of organic aerosol using offline aerosol mass spectrometry. Atmos Meas Tech 9:23-39. https://doi.org/10.5194/amt-9-23-2016

Deniver van der Gon HAC, Bergström R, Fountoukis C, Johansson C, Pandis SN, Simpson D, Visschedijk AJH (2015) Particulate emissions from residential wood combustion in Europe-revised estimates and an evolution. Atmos Chem Phys 15:6503-6519. https://doi.org/10.5194/acp-15-6503-2015

EEA-European Environment Agency Report, (2019) Air quality in Europe-2019 report

Eze IC, Hemkens LG, Bucher HC, Hoffman B, Schindler C, Künzli N, Schikowski T, Probst-Hensh NN (2015) Association between ambient air pollution and diabetes mellitus in Europe and North America: systematic review and meta-analysis. Environ Health Perspect 123(5):381-389. https://doi.org/10.1289/ehp.1307823

Faraca G, Boldrin A, Astrup T (2019) Resource quality of wood waste: THE importance of physical and chemical impurities in wood waste for recycling. Waste Manage 87:135-147. https://doi.org/ 10.1016/j.wasman.2019.02.005

Garcia R, Pizarro C, Alvarez A, Lavin AG, Bueno JL (2015) Study of biomass combustion wastes. Fuel 148:152-159. https://doi.org/ 10.1016/j.fuel.2015.01.079

Gąsiński A, Poszytek A (2013) Zastosowanie metody Rietvelda do ilościowego oznaczania skłądu mineralnego skał łupkowychimplikacje do poszukiwań i eksploatacji niekonwencjonalnych złóż gazu ziemnego (gazu "łupkowego"). Nafta-Gaz 3:213-229 ((in Polish))

GUS - Statistics Poland - Statistical analyses, (2019) Energy consumption in households in 2018, Warsaw 2019 (Poland)

Jagustyn B, Bątorek-Giesa N, Wilk B (2011) Ocena włąściwości biomasy wykorzystywanej do celów energetycznych. CHEMIK 65(6):557-563

Jakubus M, Tatuśko N (2016) Evaluation of metals bioavailability in agricultural soil treated with wood biomass. Polish J Soil Sci 2:195-297. https://doi.org/10.17951/pjss/2016.49.2.195

Jukić M, Ćurković L, Šabarić J, Kerolli-Mustafa M (2017) Fractionation of heavy metals in fly ash from wood biomass using the BCR sequential extraction procedure. Bull Environ Contam Toxicol 99:524-529. https://doi.org/10.1007/s00128-017-2160-0

Kajda-Szcześniak M (2014) Characteristic of ashes from fireplace. Archives Waste Manage Environ Protect 16(3):73-78

Kasangana KK, Chadyiwa M, Masekameni D, Makonese T (2017) Exposure to wood dust and health effects: a review of epidemiological evidences from developing countries. In: Conference: National Association for Clean Air At: Johannesburg, South Africa

Kistler M, Schmidl C, Padouvas E, Giebl H, Lohninger J, Ellinger R, Bauer H, Puxbaum H (2012) Odor, gaseous and $\mathrm{PM}_{10}$ emissions from small scale combustion of wood types indigenous to Central Europe. Atmos Environ 51:86-93. https://doi.org/10.1016/j.atmos env.2012.01.044

Koukouzas N, Wardb CR, Papanikolaoua D, Li Z, Ketikidis C (2009) Quantitative evaluation of minerals in fly ashes of biomass, coal and biomass-coal mixture derived from circulating fluidised bed combustion technology. J Hazard Mater 169:100-107. https://doi. org/10.1016/j.jhazmat.2009.03.116

Kowalkowski A, Olejarski J (2013) Possibilities of using ashes from forest biomass as a source of nutrients (Możliwości wykorzystania popiołów z biomasy leśnej jako źródła elementów odżywczych). In: Biomasa leśna na cele energetyczne. Red. naukowa P. Gołas i A. Kaliszewski. Prace Instytutu Badawczego Leśnictwa, Sękocin Stary, 147-176 (in Polish)

Kubica K, Kubica R, (2016) Założenia bazy danych wskaźników emisji dla kalkulatora emisji zanieczyszczeń z urządzeń grzewczych na paliwa stałe. Raport dla Instytutu Ekonomii Środowiska, Gliwice, pp 1-18 (in Polish)

Lanzerstorfer C (2015) Chemical composition and physical properties of filter fly ashes from eight grate-fired biomass combustion plants. J Environ Sci 30:191-197. https://doi.org/10.1016/j.jes. 2014.08.021

Maasikmets M, Kupri HL, Teinemaa E, Vainumäe K, Arumäe T, Roots O, Kimmel V (2016) Emissions from burning municipal solid waste and wood in domestic heaters. Atmospheric Pollut Res 7:438-446. https://doi.org/10.1016/j.apr.2015.10.021

Maenhaut W, Vermeylen R, Claeys M, Vercauteren J, Matheeussen C, Roekens E (2012) Assessment of the contribution from wood burning to the PM10 aerosol in Flanders, Belgium. Sci Total Environ 437:226-236. https://doi.org/10.1016/j.scitotenv.2012.08.015

Magdziarz A, Gajek M, Nowak-Woźny D, Wilk M (2018) Mineral phase transformation of biomass ashes-Experimental and thermochemical calculation. Renew Energy 128:446-459. https://doi. org/10.1016/j.renene.2017.05.057

Maresca A, Hyks J, Astrup TF (2017) Recirculation of biomass ashes onto forest soils: ash composition, mineralogy and leaching proprieties. Waste Manage 70:127-138. https://doi.org/10.1016/j. wasman.2017.09.008

Martin M, Tritscher T, Jurányi Z, Heringa MF, Sierau B, Weingartner E, Gysel M, Prévôt ASH, Baltensperger U, Lohmann U (2013) Hygroscopic properties of fresh and aged wood burning particles. J Aerosol Sci 56:15-29. https://doi.org/10.1016/j.jaerosci.2012. 08.006

Maschio S, Tonello G, Piani L, Furlan E (2011) Fly and bottom ashes from biomass combustion as cement replacing components in mortars production: Rheological behaviour of the pastes and materials compression strength. Chemosphere 85:666-671. https://doi.org/10.1016/j.chemosphere.2011.06.070

Meij R (1994) Trace element behavior in coal-fired power plants. Fuel Process Technol 39:199-217

Michalik M, Wilczyńska-Michalik W (2012) Mineral and chemical composition of biomass ash. Europ Mineralogical Conference 1:423. https://doi.org/10.13140/2.1.4298.5603

Mirowski T (2016) Utilization of biomass for energy purpose versus reduction of emission of air pollutants from municipal and household sector. Rocznik Ochrony Środowiska 18:466-477

Mirowski T, Mokrzycki E, Uliasz-Biocheńczyk A (2018) Energetyczne wykorzystanie biomasy. Wyd. IGSMiE PAN, Kraków (in Polish)

Morakinyo OM, Mokgobu MI, Mukhola MS, Hunter RP (2016) Heath outcomes of exposure to biological and chemical components oh inhalable and respirable particulate matter. Int J Environ Res Public Heath 13:592. https://doi.org/10.3390/ijerph13060592

Nunes L, Matis J, Catalão J (2016) Biomass combustion systema review on the physical and chemical properties of the ashes. Renev Sustain Energy Rev 53:235-242. https://doi.org/10.1016/j. rser.2015.08.053

Padilla-Barrera Z, Torres-Jardón R, Ruiz-Suarez LG, Castro T, Peralta O, Saavedra MI, Masera O, Molina LT, Zavala M (2019) Determination of emission factors for climate forcers and air pollutants from improved wood-burning cookstoves in Mexico. Energy Sustain Develop 50:61-68. https://doi.org/10.1016/j.esd.2019.02.004 
PN-EN ISO 17225-1:2014-07 (2014) Solid biofuels-fuel specifications and grades. Part 1: General requirements

PN-EN ISO 17225-2:2014-07 (2014) Solid biofuels-fuel specifications and grades. Part 2: Wood pellets for non-industrial use

PN-EN ISO 17225-3:2014-07 (2014) Solid biofuels-fuel specifications and grades. Part 3: Wood briquettes for non-industrial use

PN-EN ISO 17225-4:2014-07 (2014) Solid biofuels-fuel specifications and grades. Part 4: Wood chips for non-industrial use

PN-EN ISO 17225-5:2014-07, (2014) Solid biofuels-fuel specifications and grades. Part 5: Firewood for non-industrial use

PN-EN ISO 18122:2016-06, (2016) Solid biofuels-Determination of ash content

PN-EN ISO 18123:2016-01, (2016) Solid biofuels-Determination of volatile matter content

PN-EN ISO 18125:2017-07, (2017) Solid biofuel-Determination of calorific value

PN-EN ISO 18134-2:2017-03, (2017) Solid biofuels—Determination of moisture content-Dryer method. Part 2: Total moisture-Simplified method

PN-EN ISO 18135:2017-06, (2017) Solid biofuels-Sampling

PN-EN ISO 14780:2017-07, (2017) Solid biofuels-Sample preparation

Riddervold IS, Bønløkke JH, Olin A, Grønborg TK, Schlünssen Skogstrand V, Hougaard D, Massling A, Sigsgaard S (2012) Effects of wood smokes particles from wood-burning stoves on the respiratory health of atopic humans. Particle Fibre Toxicol 9(12):1-13. https://doi.org/10.1186/1743-8977-9-12

Ristovski ZD, Wardoyo AY, Morawska L, Jamriska M, Carr S, Johnson G (2010) Biomass burning influenced particles characteristics in Northern territory Australia Based on airborne measurements. Atmospheric Res 96(1):103-109. https://doi.org/10.1016/j.atmos res.2009.12.002

Robinson T, Mohan M, Chilukoti B, Sasmal S, Banerjee T, Goud VV (2015) Optimization of dilute acid and hot water pretreatment of different lignocellulosic biomass: comparative study. Biomass Bioenerg 81:9-18. https://doi.org/10.1016/j.biombioe.2015.05. 006

Rybak W (2006) Spalanie i współspalanie biopaliw stałych. Wyd. Oficyny Wydawniczej Politechniki Wrocławskiej, Wrocław (in Polish)

Sano T, Miura S, Furusawa H, Kaneko S, Yoshida T, Nomura T, Ohara $S$ (2013) Composition of 675 inorganic elements and the leaching behavior of biomass combustion ashes discharged from wood pellet 676 boilers in Japan. J Wood Sci 59:307-320. https://doi. org/10.1007/s10086-013-1337-3

Shi R, Li J, Jiang J, Mehmood K, Liu Y, Xu R, Qian W (2016) Characteristics of biomass ashes from different materials and their ameliorative effects on acid soils. J Environ Sci. In Press, Corrected Proof. https://dx.doi.org/https://doi.org/10.1016/j.jes.2016.07.015

Siergiej P, Jędrak J (2019) Kominki. Czy spalanie drewna jest problemem? Spalanie drewna w kominkach w Polsce i na świeciewpływ na jakość powietrza i stan zdrowia. Regulacje prawne i polityka antysmogowa w wybranych krajach. Warszawa (Poland) (in Polish)

Schmidl C, Marr IL, Caseiro A, Kotianowá P, Berner A, Bauer H, Kasper-Giebl A, Puxbaum H (2007) Chemical characterisation of fine particle emissions from wood stove combustion of cammon woods growing in mid-European Alpine regions. Atmospheric Environ 42:126-141. https://doi.org/10.1016/j.atmosenv.2007. 09.028

Schober P, Boer C, Schwarte LA (2018) Correlation coefficients: Appropriate use and interpretation. Anesthesia Analgesia 126(5):1763-1768. https://doi.org/10.1213/ANE.0000000000 002864

Supanic K, Oberberger I, Kienzl A, Arich A (2014) Conversion and leaching characteristics of biomass ashes during outdoor storage - results laboratory tests. Biomass Bioenergy 61:211-226. https://doi.org/10.1016/j.biombioe.2013.12.014

Symanowicz B, Becher M, Jaremko D, Skwarek K (2018) Possibilities for the use of wood ashes in agriculture. J Ecol Eng 19(3):191196. https://doi.org/10.12911/22998993/86156

Szwalec A, Mundała P, Kedzior R, Telk M, Gawroński P (2016) Zróżnicowanie zawartości $\mathrm{Cd}, \mathrm{Pb}, \mathrm{Zn}$ i Cu w biomasie wykorzystywanej na cele energetyczne (Diversity of $\mathrm{Cd}, \mathrm{Pb}, \mathrm{Zn}$ and $\mathrm{Cu}$ content in the biomass used for energy purposes). Acta Sci Pol Formatio Circumiectus 15(4):343-351. https://doi.org/10.15576/ ASP.FC/2016.15.4.343

Tao J, Zhang L, Zhang R, Wu Y, Zhang Z, Zhang Y, Tang Y, Cao Y, Zhang Y (2016) Uncertainty assessment of source attribution of PM25 and its water-soluble organic carbon content using different biomass burning tracers in positive matrix factorization analysisa case study in Beijing China. Sci Total Environ 543(7):326-335. https://doi.org/10.1016/j.scitotenv.2015.11.057

Thy P, Barfod GH, Cole AM, Brown EL, Jenkins BM, Lesher CE (2017) Trace metal release during wood pyrolysis. Fuel 203:548556. https://doi.org/10.1016/j.fuel.2017.04.050

Trojanowski R, Fthenakis V (2019) Nanoparticle emissions from residential wood combustion: a critical literature review, characterization, and recommendations. Renew Sustain Energy Rev 103:515-528. https://doi.org/10.1016/j.rser.2019.01.007

Uliasz-Bocheńczyk A, Mokrzycki E (2018) The elemental composition of biomass ashes as a preliminary assessment of the recovery potential. Mineral Resour Manage 34(4):115-132. https://doi.org/ $10.24425 / 122593$

Vassilev SV, Baxter D, Andersen L, Vassileva CG (2010) An overview of the chemical composition of biomass. Fuel 89:913-933. https:// doi.org/10.1016/j.fuel.2009.10.022

Vassilev SV, Baxter D, Andersen LK, Vassileva CG, Morgan TJ (2012) An overview of the organic and inorganic phase composition of biomass. Fuel 94:1-33. https://doi.org/10.1016/j.fuel.2011.09.030

Vassilev S, Baxter D, Andersen L, Vassileva CG (2013) An overview of the composition and application of biomass ash. Part 1. Phase-mineral and chemical composition and classification. Fuel 105:40-76. https://doi.org/10.1016/j.fuel.2012.09.041

Vassilev SV, Vassileva CG, Baxter D (2014) Trace element concentrations and associations in some biomass ashes. Fuel 129:292-313. https://doi.org/10.1016/j.fuel.2014.04.001

Vincente E, Alves C (2018) An overview of particulate emissions from residential biomass combustion. Atmospheric Res 199(1):159185. https://doi.org/10.1016/j.atmosres.2017.08.027

Wang S, Miller A, Llamazos E, Fonseca F, Baxter L (2008) Biomass fly ash in concrete: mixture proportioning and mechanical properties. Fuel 87:365-371. https://doi.org/10.1016/j.fuel.2007.05.026

WHO-World Health Organization, (2015) World Report on Ageing and Health

Wiinikka H, Grönberg C, Boman C (2013) Emissions of heavy metals during fixed-bed combustion on six biomass fuels. Energy Fuels 27(2):1073-1080. https://doi.org/10.1021/ef3011146

Wisz J, Matwiejew A (2005) Biomasa - badania w laboratorium w aspekcie przydatności do energetycznego spalania (Bio-Mass Laboratory Tests Concerning It Usefulness for Power Combustion). Energetyka 9:631-636

Yeboah NNN, Shearer ChR, Burns SE, Kurtis KE (2014) Characterization of biomass and high carbon content coal ash for productive ruse applications. Fuel 116:438-447. https://doi.org/10.1016/j. fuel.2013.08.030

Zając G, Szyszlak-Bargłowicz J, Gołębiowski W, Szczepanik M (2018) Chemical characteristic of biomass ashes. Energies 11:2885. https://doi.org/10.3390/en11112885 